\title{
sztuka
}

tom 2, 2014

Przemystaw Waszak

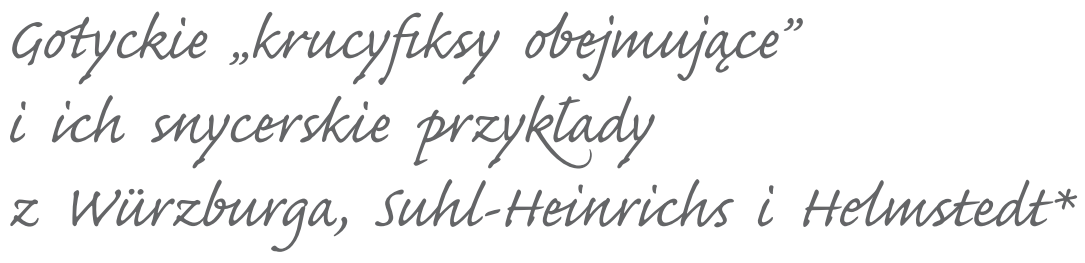

Niniejszy artykuł traktuje o wyraźnie wyodrębnionym, charakterystycznym oraz interesującym ikonograficznie typie rzeźb i malowideł przedstawiających Ukrzyżowanego Chrystusa. Rozważania obejmą przede wszystkim trzy snycerskie „krucyfiksy obejmujące” datowane na XIV wiek. O ich wyborze zadecydowała zasadnicza różnica pomiędzy nimi a przedstawieniami malarskimi i późniejszymi, tego samego typu ikonogra-

* Badania nad tym zagadnieniem zostały sfinansowane w ramach dwóch grantów Wydziału Nauk Historycznych UMK: nr 2027-NH i nr 477-NH. W przygotowaniu artykułu pomocne było stypendium Polskiej Misji Historycznej w Würzburgu przeprowadzone w listopadzie 2010 r. Pierwsza wersja artykułu została zaprezentowana 12 XII 2008 r. na konferencji w Toruniu: „Znak - Symbol - Alegoria. Znaczenia sztuki i znaczenia w sztuce”. Pragnąłbym bardzo podziękować za naukowe wskazówki oraz dyskusje Panu dr. hab. Ryszardowi Mączyńskiemu, prof. UMK, Pani prof. dr hab. Marii Poksińskiej, Panu dr. hab. Albertowi Boesten-Stenglowi, prof. UMK, oraz Panu dr. hab. Jarosławowi Jarzewiczowi, prof. UAM. Chciałbym uprzejmie podziękować za życzliwe udostępnienie zdjęć i pozwoleń na ich publikację probostwu (Dompfarramt) St. Kilian w Würzburgu, Angermuseum w Erfurcie, Soprintendenza per i Beni Storici Artistici ed Etnoantropologici dell'Umbria w Perugii, Niedersächsisches Landesamt für Denkmalpflege w Hanowerze, Ev.-luth. Kirchengemeinde St. Marienberg w Helmstedt i Pani pastor (Pfarrerin) Lena Stark oraz Pani Gudrun Klaffehn. 
ficznego. Omawiana grupa niemieckich, snycerskich obiektów jest szczególnie mało liczna. Można wymienić przykłady przede wszystkim z kościoła Neumünster w Würzburgu (il. 1-4) oraz z Heinrichs bei Suhl (obecnie w Angermuseum w Erfurcie, il. 5), wyraźne podobieństwa wykazuje także krucyfiks z kościoła St. Marienberg w Helmstedt, pochodzący z kaplicy szpitala św. Jerzego na Neumark - przedmieściu Helmstedt ${ }^{1}$ (il. 6-9).

Analizie i porównaniom poddany został szereg dzieł sztuki - wizualnych obiektów. Przedstawiono ich kontekst w średniowiecznych dziełach literackich, szczególnie w tekstach mistycznych. Artykuł ma również na celu pokazanie odniesień pomiędzy średniowieczną kulturą pisaną - będącą zarazem odblaskiem ówczesnej kultury ustnej - a dziełami sztuki. Pod koniec artykułu został podjęty powiązany temat Alegorii Dobrej i Złej Modlitwy.

W literaturze naukowej pojawiły się odwołania do innych, nieco zbliżonych ikonograficznie do gotyckich „krucyfiksów obejmujących”, obiektów rzeźbiarskich. Można wymienić niemiecki tryptyk z kości słoniowej ze zbiorów rzemiosła artystycznego (Kunstgewerbesammlungen) w muzeum w Berlinie, kamienny relief na Spital w Kastl i przede wszystkim dzieła sztuki, które dawniej były łączone z opisywanym typem: kamienne z kościoła św. Marcina w Forchheim i snycerskie z muzeum we Wrocławiu, pochodzące z Saksonii². Większość z tych przykładów nie była od siebie zbyt odległa, co pokazują mapy topograficzne.

Grażyna Jurkowlaniec, rozważając kwestie wpływu innych przedstawień ikonograficznych na typ Męża Boleści (Chrystusa Umęczonego), wymieniła „krucyfiksy obejmujące”3.

1 Kapelle des Hospitals St. Georg (S. Georgii), P. J. Meier, Die Bau- und Kunstdenkmäler des Kreises Helmstedt, Wolfenbüttel 1896, s. 80 n. Krzyż datowany jest na koniec XV w.: Deutsche Inschriften 61, Stadt Helmstedt, Nr. 28 (Ingrid Henze), www.inschriften.net, urn:nbn:de:0238-di061g011k0002804, dostęp 10 X 2014. O krucyfiksie z Helmstedt zob. też: G. von der Osten, Der umarmende Kruzifixus in Helmstedt, „Niederdeutsche Beiträge zur Kunstgeschichte”, VI, 1967, s. 111 n.

2 A. Zimmermann, Jesus Christus als „Schmerzensmann” in hoch-und spätmittelalterlichen Darstellungen der bildenden Kunst: eine Analyse ihres Sinngehalts, Martin-Luther-Universität Halle-Wittenberg, dysertacja obroniona 27 XI 1997 roku, http://sundoc.bibliothek. uni-halle.de/diss-online/97/98H110/, dostęp 20 III 2007 r., s. 107 n., 110, 146, 499.

G. Jurkowlaniec, Chrystus Umęczony. Ikonografia w Polsce od XIII do XVI wieku, Warszawa 2001, s. 36, 37. Autorka cytuje w sprawie trudnego do wyjaśnienia typu krucy- 
W krucyfiksie z Würzburga tułów Chrystusa przylega do krzyża. Stopy przebito jednym gwoździem. Natomiast ramiona zostały oderwane od poziomej belki krzyża i znajdują się w niezbyt dużej odległości od klatki piersiowej. Zaakcentowano wciąż tkwiące w dłoniach wydatne, długie gwoździe. Gest rąk przypomina obejmowanie czegoś, niewielkiej przestrzeni, przytulanie dziecka lub wzięcie kogoś w ramiona przez Chrystusa. Jezus z namaszczeniem i serdecznie kieruje swoją głowę i częściowo również wzrok ku tej niewielkiej przestrzeni.

Ten typ krucyfiksu jest niejednoznacznie klasyfikowany w literaturze. W niemieckiej historii sztuki „krucyfiksy obejmujące” nazywane są - tak samo - Umarmende Kruzifixus lub po prostu Kruzifixus. Warto zwrócić uwagę, że właściwie nawet częściej określa się je jako Umarmende Schmerzensmann, czyli Obejmujący Mąż Boleści lub Schmerzensmann am Kreuz - Mąż Boleści na krzyżu. Można spotkać nawet nazwę: Man of Sorrows crucifix. To ostatnie określenie łączy oba typy przedstawieniowe Jezusa Chrystusa i zostało oparte na ich charakterystycznych cechach. Czasem obejmujące krucyfiksy nazywa się opisowo: Crucifix with his arms taken away from the Cross - Krucyfiks z ramionami oderwanymi od krzyża. Erwin Panofsky, analizując typy Męża Boleści, cytował „krucyfiksy obejmujące” z Heinrichs bei Suhl i Würzburga ${ }^{4}$. Andrea Zimmermann w swojej ważnej dysertacji z 1997 roku przekonywała, że powinno się używać określenia Schmerzensmann - Mąż Boleści, a nie „krucyfik””.

Biorąc pod uwagę cechy omawianych przedstawień Zbawiciela, rozważałbym raczej termin „krucyfiks obejmujący” aniżeli Mąż Boleści. Warto zaakcentować, że Chrystus ukazany został wyraźnie jako przybity do wydatnego krzyża, jego stopy cały czas pozostają przybite. W mistycznych

fiksów obejmujących: G. von der Osten, Der Schmerzensmann: Typengeschichte eines deutschen Andachtsbildwerkes von 1300 bis 1600, Berlin 1935, s. 49 n. Natomiast w kwestii roli wizji mistycznych: W. Marcinkowski, Przedstawienia dewocyjne jako kategoria sztuki gotyckiej, Kraków 1994, s. 90 i przyp. 287.

4 E. Panofsky, Imago pietatis. Przyczynek do historii typów przedstawieniowych. Maż Boleści i Maryja Pośredniczka, [w:] idem, Średniowiecze, Warszawa 2001, s. 246, przyp. 69; G. Schiller, Ikonographie der christlichen Kunst, t. 2: Die Passion Jesu Christi, Gütersloh 1968, s. 160, 280; J. Emmert, Neumünster Würzburg, English edition, Regensburg 2010, s. $12,15$.

5 A. Zimmermann, op. cit., s. 499 n. 
średniowiecznych wizjach znajdują się opisy Jezusa Chrystusa, który tylko na chwilę oderwał swoje ramiona od poziomej belki krzyża.

„Krucyfiksy obejmujące” zawierają się w znacznie szerszym typie krucyfiksów mistycznych, nazywanych też krzyżami epidemicznymi - Pestkreu$z e$, których powstawanie miało związek z epidemiami nękającymi ludzkość ${ }^{6}$.

Można wskazać jeszcze jedną kwestię terminologiczną. Czy należy mówić o „krucyfiksach obejmujących”, umieszczając w cudzysłowie ich najbardziej charakteryzujący epitet, czy można zinterpretować ten gest inaczej? Układ rąk Ukrzyżowanego nie jest ani oczywisty, ani jasny. Nie widać osoby, która jest obejmowana, a tylko niewielką, pustą przestrzeń, która może symbolizować świętego, osobę, która została objęta, przytulona przez cierpiącego Chrystusa. Gest utrwalony w rzeźbiarskich krucyfiksach przywołuje również gest modlitwy. Wykazuje on podobieństwo do aniołów wyrzeźbionych na marmurowym retabulum w kościele św. Franciszka w Pizie, przypisywanych Tommaso Piseno ${ }^{7}$. Reliefowe anioły towarzyszą stojącej figurze Matki Boskiej z Dzieciątkiem Jezus. Można by zaryzykować nazwanie rozważanych dzieł sztuki krucyfiksami „w modlitwie”, „modlącymi się”. W Biblii znajdują się słowa mówiące, że Chrystus podczas swojego życia na Ziemi również modlił się do Boga Ojca. Warto dla przykładu wymienić modlitwę w Ogrodzie Oliwnym (Getsemani). Jezus Chrystus modlił się w nocy poprzedzającej jego Ukrzyżowanie. Gdy był przybity do krzyża, znowu kilka razy wymówił słowa skierowane do Boga Ojca, co zostało przekazane przez Ewangelie. Gesty, które można spróbować łączyć z modlitwą, można też zaobserwować w przedstawieniach niektórych aniołów autorstwa Giotta. Aczkolwiek gesty podobne do tych obecnych w snycerskich „krucyfiksach obejmujących” występują bardzo rzadko. Jako przykład można wskazać fresk obrazujący Narodziny Chrystusa w kościele św. Franciszka w Asyżu, datowany na drugą dekadę XIV wieku. Taki gest demonstruje zaledwie jeden $\mathrm{z}$ aniołów lecących ponad dachem stajenki oraz jeden poniżej dachu. W ge-

6 Różne nazwy krucyfiksów mistycznych wyjaśniła: M. von Alemann-Schwartz, Crucifixus dolorosus. Beiträge zur Polychromie und Ikonographie der rheinischen Gabelkruzifi$x e$, Diss. MS, Rheinische Friedrich-Wilhelms Universität (H. von Einem, R. Haussherr), Bonn 1976, s. 12, 13.

H. Belting, Das Bild und sein Publikum im Mittelalter. Form und Funktion früher Bildtafeln der Passion, Berlin 2000, il. 35. 
stach pozostałych aniołów ludzie XX i XXI wieku łatwo rozpoznają oznakę modlitwy z uwagi na charakterystyczne złożenie dłoni. Ale dwa wymienione anioły nie modlą się tak, jak ich towarzysze. Obejmują swoimi rękami małą przestrzeń, a ich dłonie nie zostały złożone do modlitwy. Natomiast ten gest jest bardzo podobny do układu rąk „krucyfiksów obejmujących”.

Przy rozważaniach nad krucyfiksami obejmującymi warto przywołać inny interesujący krucyfiks datowany na XIV wiek, a więc podobnie do snycerskich „krucyfiksów obejmujących”. Wyrzeźbiony w drewnie krucyfiks znajduje się w Muzeum Archidiecezjalnym we Wrocławiu i jest mniej więcej naturalnej wielkości. Chrystus ma szeroko otwarte oczy, podobnie jak ten na krucyfiksie z Würzburga, ale jego ręce pozostają przybite do poziomej belki krzyża. Ukrzyżowany z Wrocławia ukazany został tak, jakby przemawiał z krzyża. Nazywa się go nawet „krucyfiksem przemawiającym i patrzącym”.

Catherine Oakes stwierdziła, że zarówno malarskie, jak i wyjątkowe rzeźbiarskie czternastowieczne „krucyfiksy obejmujące” mogły zostać zainspirowane wizją Bernarda z Clairvaux, nazywanego także Bernardem z Fontaine (zm. 1153). Ten cysterski święty był aktywny w pierwszej połowie XII wieku. Rzadziej cytuje się podobne wizje Franciszka z Asyżu (zm. 1226) i Tomasza z Akwinu (zm. 1274). Oakes wskazała również, że czasem trudno jest wyobrazić sobie obejmowaną osobę - tak małą przestrzeń zostawił twórca pomiędzy rękami a klatką piersiową Zbawiciela ${ }^{8}$. Należy jednak przyznać, że w przypadku krucyfiksu z Würzburga przestrzeń na obejmowaną osobę jest zauważalnie większa aniżeli w krucyfiksach z Suhl i Helmstedt. Ikonografię średniowiecznych przedstawień Bernarda z Clairvaux omówił James France, nie wymieniając rozważanych w niniejszym artykule źródeł mistyki nadreńskiej ani trzech gotyckich, snycerskich „krucyfiksów obejmujących”, w których rzeczywiście brak figury świętego. Zajął się natomiast licznymi przewijającymi się w średniowiecznej literaturze i sztuce toposami zbliżonymi do motywu objęcia, nadmieniając również o relacjach Zdjęć z krzyża do ilustracji bernardyńskiej wizjị9.

8 C. Oakes, Crucifix, Sculpted, Medieval, [w:] The Dictionary of Art, t. 8, red. J. Turner, New York 1998, s. 214.

9 J. France, Medieval images of Saint Bernard of Clairvaux, Kalamazoo 2007, zwł. s. XXIII, XXIX, 179 n. 
W większości słownikowych haseł opisujących przedstawienia ikonograficzne Bernarda pominięte zostały średniowieczne snycerskie przykłady „krucyfiksów obejmujących”. Ale zarówno ta wizja, jak i pewne cechy właściwe średniowiecznej, mistycznej pobożności mogą stanowić źródło rzeźbiarskich przedstawień, a przynajmniej ich paralelę, kluczowy kontekst.

Legendarną wizję cudownego zdarzenia, którego doświadczył Bernard z Clairvaux, przekazaną później przez Konrada z Eberbach (zm. 1221), napotkać można w literackim dziele O krucyfiksie obejmującym [św.] Bernarda (De crucifixo Bernardum amplexante): „Wielebny mnich Menard, dawny opat z Mores, klasztoru sąsiadującego z Clairvaux, opowiedział następującą cudowną opowieść, tak jak gdyby ona zdarzyła się komuś inne$\mathrm{mu}$, ale, jak uważamy, odnosiła się do niego samego: Słyszałem o pewnym mnichu, który kiedyś natrafił na błogosławionego opata Bernarda samego w kościele pogrążonego w modlitwie. Gdy leżał on twarzą do ziemi przed ołtarzem, pojawił się na podłodze przed nim krzyż z Ukrzyżowanym. Ten najbardziej błogosławiony człowiek nabożnie oddał mu cześć i pocałował Go. Następnie sam Chrystus oddzielił swoje ramiona od belek krzyża i wydawał się obejmować sługę bożego i skłaniać się do niego. Mnich, który był tego świadkiem, obserwując przez chwilę, nie posiadał się ze zdumienia. Obawiając się, że przeszkodzi swojemu świątobliwemu ojcu, gdyby został zauważony, obserwując z tak bliska jego tajemnice, oddalił się w ciszy, rozumiejąc, że cała modlitwa i życie tego świątobliwego męża były czymś więcej niż ludzką kondycją"10.

10 Ibidem, s. 181 n., tłum. moje. „Domnus Menardus, quondam abbas de Moris, quod est monasterium vicinum Claraevalli, vir religiosus, mirabilem quandam rem, quasi de alio, retulit familiaribus suis, quam tamen sibimet evenisse putamus, ita dicens: Notus est mihi monachus quidam, qui Bernardum abbatem aliquando reperit in ecclesia solum orantem. Qui cum prostratus esset ante altare, apparebat ei quaedam crux cum suo crucifixo super pavimentum, posita coram illo, quam isdem vir beatissimus devotissime adorabat ac deosculabatur. Porro ipsa majestas, separatis brachiis a cornibus crucis, videbatur eundem Dei famulum amplecti, atque astringere sibi: quod dum monachus ille aliquandiu cerneret, prae nimia admiratione stupidus haerebat, et quasi extra se erat. Tandem vero metuens ne Patrem sanctum offenderet, si eum veluti secretorum suorum exploratorem, ita sibi de proximo imminere conspiceret, silenter acscessit, intelligens nimirum ac sciens de illo homine sancto, quod vere supra hominem esset tota ipsius oratio, atque conversatio". Konrad von Eberbach, Exordium Magnum 2:7 (Exordium Magnum Cisterciense, red. B. Griesser, Roma 1961, s. 102 n.). Za: J. France, op. cit., s. 182, przyp. 12. W nieznacznie 
Bardzo podobna, niemal identyczna do cytowanej jest wizja przekazana przez Herberta z Clairvaux (zm. około 1198) ${ }^{11}$. Główną różnicą jest bardziej rozbudowany tytuł. Ten przekaz mógł nawet poprzedzać dzieło Konrada z Eberbach, stanowić dla niego źródło.

Inna, nie tak szeroko znana ani rozpowszechniona jest wizja Ruperta von Deutz (zm. około 1130). Mówi on o wizji naprzeciwko ołtarza z krucyfiksem. Opowiada o objęciu, czułym przytuleniu oraz o pocałunku Ukrzyżowanego. Wymienia krucyfiks: „crucifixum et viventem oculos in me apertos habentem”12 („Który ma swoje żywe oczy otwarte i patrzy na mnie”).

Może zaskakiwać, że legendarna wizja cysterskiego świętego, żyjącego w pierwszej połowie XII wieku, przekazana przed 1221 rokiem - a w innych odmianach nawet wcześniej - zostaje ukazana w rzeźbie dopiero po roku 1300, jak możemy sądzić po zachowanych przykładach. Z drugiej strony częstsze są przedstawienia tej wizji Bernarda dopiero w XV wie$\mathrm{ku}^{13}$. Co więcej, typ Amplexus został stworzony i zastosowany w sztuce na północ od Alp, zapewne, według cytowanych przykładów, głównie w krajach niemieckojęzycznych. W Hiszpanii pojawia się po raz pierwszy w baroku, podczas gdy na południe od Alp - we Włoszech nie przyjął się ${ }^{14}$. Częściej spotyka się go w późnogotyckim, niemieckim malarstwie

odmiennych słowach również w dziewiętnastowiecznym wydaniu: Konrad von Eberbach, S. Bernardi vita et res gestae libris septem comprehensae. Liber septimus, excerptus ex libro cui titulus »Exordium magnum Cisterciense «, Caput VII. De crucifixo Bernardum amplexante, [w:] Patrologia Latina. S. Bernardi Abbatis Primi Clarae-vallensis Opera omnia, red. J. P. Migne, t. 185, Paris 1860, szp. 419 n.

11 Herbert de Clairvaux, De miraculis libri tres. Liber secundus. Caput XIX. Orantis S. Bernardo apparens Christus crucifixus, solutis a cruce brachiis eum amplectitur, [w:] Patrologia Latina. S. Bernardi Abbatis Primi Clarae-vallensis Opera omnia, red. J. P. Migne, t. 185 , Paris 1860, szp. 1328.

12 A. Zimmermann, op. cit., s. 500, przyp. 536. R. von Deutz, De gloria et honore Filii Hominis super Matthaeum. Liber duodecimus, [w:] Patrologia Latina. R. D. D. Ruperti abbatis monasterii $S$. Heriberti Tuitiensis. Viri longae doctissimi summique inter veteres theologi Opera omnia, t. 168, red. J. P. Migne, Paris 1854, szp. 1601.

13 G. Binding, B. v. Clairvaux, [w:] Lexikon des Mittelalters, t. 1, cz. 10, red. L. Lutz, München 1980, szp. 1997.

14 H. Aurenhammer, Lexikon der christlichen Ikonographie, t. 1: Alpha und Omega-Christus und die vierundzwanzig Ältesten, Wien 1967, s. 339 n.; Ch. Squarr, Bernhard von Clairvaux, [w:] Lexikon der christlichen Ikonographie, t. 5, wyd. E. Kirschbaum; red. W. Braunfels, Rom 1973, szp. 378 n. 
tablicowym ${ }^{15}$. Rzeźbiarskie wersje obrazów dewocyjnych o tym temacie można więc określić jako wyjątkowe, z uwagi na ich wczesne datowanie, monumentalność i autonomię - niezależne, samodzielne przedstawienia. Typ Amplexus to jeden z trzech typów ikonograficznych Bernarda z Clairvaux. Dwa pozostałe nazywane są doctrina oraz lactatio $^{16}$. Rozpowszechnienie krucyfiksów w typie Amplexus odpowiada drodze recepcji w dziełach sztuki motywu Drzewa Życia Bonawentury (zm. 1274), to znaczy krzyża z 12 żywymi, ozdobionymi konarami. Droga bonawenturiańskiego motywu wiodła od rysunków wykonanych przez samego świętego, poprzez iluminacje i malarstwo tablicowe do monumentalnych fresków i rzeźb ${ }^{17}$.

„Krucyfiksy obejmujące” są ponadnaturalnej lub naturalnej wielkości. Najbardziej znaczący w Würzburgu ma $220 \mathrm{~cm}$ wysokości, natomiast Pasja z Heinrichs bei Suhl: 189 cm. Zaskakuje, że ramiona krucyfiksów znajdują się dość blisko klatki piersiowej i obejmują zaledwie małą przestrzeń. Pozostaje niewiele miejsca dla obejmowanego świętego, którego trzeba sobie wyobrazić. W tej kwestii w szczególności krucyfiks z Helmstedt bardziej przypomina rzeźbione figury Chrystusa w grobie, które mają skrzyżowane na piersi ręce. Dla przykładu warto wymienić gotycką, snycerską figurę Chrystusa w grobie w Muzeum Okręgowym w Toruniu, która pochodzi z gotyckiego, pofranciszkańskiego kościoła Mariackiego w Toruniu. Porównując te figury - stojących krucyfiksów oraz leżących figur Chrystusa w grobie - rozważam przede wszystkim gest skrzyżowanych rąk leżących na piersi Chrystusa, najbardziej ewidentny w drugim z wymienionych typów ikonograficznych. Jakże odmiennie od gotyckich rzeźb prezentują się pod tym względem malarskie dzieła sztuki przedstawiające wizję obejmującego Jezusa Chrystusa, którego rozpostarte ramiona wyraźnie obejmują Bernarda. Krucyfiks z Helmstedt to, spośród trzech gotyckich „krucyfik-

15 H. Sachs, E. Badstübner, H. Neumann, Christliche Ikonographie in Stichworten, Berlin 1996, s. 58.

16 H. Lesman, H. Wegner, Bernard z Clairvaux. VII. Ikonografia, [w:] Encyklopedia katolicka, t. 2, red. F. Gryglewicz, R. Łukaszyk, Z. Sułowski, Lublin 1976, szp. 307.

17 Powstały liczne kopie rękopiśmienne literackiego „Drzewa Życia”. Zostało ono również zilustrowane w malowidłach i kodeksach: K. Żuchowski, Drzewo Życia, wprowadzenie, [w:] św. Bonawentura, Pisma ascetyczno-mistyczne, Warszawa 1984, s. 260. 
sów obejmujących", dzieło o najbardziej uspokojonym wyrazie. Bije z niego nabożność, wielka czułość i serdeczność połączona z dozą elegijności i pobożnego wycofania. Takie cechy sugeruje układ rąk, wyraz fizjonomii, delikatne pochylenie głowy i tułowia.

Przedstawienia krucyfiksów obejmujących nieodparcie przywołują znacznie starszy typ przedstawienia związanego z Pasją Jezusa. Jest on zdecydowanie bardziej ugruntowany i rozpowszechniony w tradycji ikonografii chrześcijańskiej. Przywołać tu należy przedstawienia Zdjęcia z krzyża. Warto wspomnieć płaskorzeźbę Benedetto Antelamiego z katedry w Parmie datowaną na 1178 rok. Ważna w tym kontekście jest także trójwymiarowa rzeźba $\mathrm{z}$ kości słoniowej z Luwru, datowana na lata 1260-1270. Z dzieł monumentalnych należy wskazać grupę rzeźb z katedry w Burgos, datowanych na rok 1265. Zbliżona jest kompozycja figur oraz wykonywanych przez nie czynności. Bernard z Clairvaux wykonuje podobną czynność, a właściwie można powiedzieć, że przejmuje funkcję Józefa z Arymatei. Podtrzymuje opadające Ciało Chrystusa ${ }^{18}$. Najważniejszy jest gest obejmowania, bardzo rozpowszechniony w sztuce i literaturze średniowiecza.

Całkowicie odmienne jest Zdjęcie z krzyża z katedry w Tivoli, datowane na lata 1220-1230. Przedstawiona tam postać pod krzyżem ujmuje ręką tylko nogę Zbawiciela. Tułów Chrystusa częściowo przylega do krzyża. Odkupiciel rozpościera swoje ramiona w geście obejmowania wszystkich wiernych znajdujących się pod wysoko umieszczonym krzyżem. Ten typ ikonograficzny Zdjęcia z krzyża pojawił się w Umbrii oraz pótnocnym Lacjum w drugiej ćwierci XIII wieku. Gest obejmowania wszystkich zgromadzonych pod krzyżem został uwydatniony przez umieszczanie takich grup Zdjęcia z krzyża na belkach tęczowych bądź ponad ołtarzami (w Burgos i Volterra) ${ }^{19}$. Warto wymienić postać Chrystusa na krzyżu z grupy Zdjęcia z krzyża z Galleria Nazionale dell'Umbria w Perugii, pocho-

18 Przykładem jest szkicowa, akwarelowa ilustracja wizji Bernarda z Clairvaux w zbiorach: Norymberga, Germanisches Nationalmuseum, Graphische Sammlung, Inv. Nr. HZ 5197 Kapsel 561, datowana na ok. 1520-1525.

19 P. Williamson, Gothic sculpture, 1140-1300, New Haven b.r. [1998], s. 133, por.: il. $189,203,209,354$. 
dzącą z kościoła Santa Maria w Roncione nieopodal Deruty (il. 10-12). Rzeźbę Chrystusa określa się jako Cristo deposto i datuje na pierwszą połowę XIII wieku, a dokładniej, według inskrypcji na podstawie krzyża, przed 1236 rokiem $^{20}$. Idea obejmowania wszystkich wiernych i wstawiania się za nimi występuje również bardzo podobnie w innym gotyckim typie ikonograficznym: Madonnie Płaszcza Ochronnego. Tak jak w snycerskich, gotyckich Madonnach Szafkowych, rozpościerających swoje opiekuńcze ramiona i szaty ponad namalowanymi poniżej i w znacznym pomniejszeniu postaciami wiernych.

Hans Belting już w 1981 roku rozważał wyróżniający się gest Jezusa Chrystusa reprezentujący objęcie. Przywoływał malarski przykład - czternastowieczne przedstawienie Męża Boleści ukazanego w sarkofagu na fresku znajdującym się obecnie w Nowym Jorku, a pochodzącym z Florencji. Uważał, że gest objęcia wyrażony w wizji Bernarda z Clairvaux wywodzi się z przedstawień Zdjęć z krzyża. Przywołał rzeźbiarski, trzynastowieczny przykład: pięcioosobową grupę z oratorium S. Antonio we włoskim Pescia $^{21}$. Obecnie wiedza o tym, że geneza „krucyfiksów obejmujących” wywodzi się z przedstawień Zdjęć z krzyża jest dość rozpowszechniona. Takie wyjaśnienie pochodzenia ikonograficznego typu Amplexus Bernarda z Clairvaux znajduje się bowiem również we współczesnym włoskim leksykonie sztuki chrześcijańskiej, koncentrującym się przede wszystkim na sztuce Italii ${ }^{22}$.

W kontraście do statycznych Ukrzyżowań, Zdjęcia z krzyża, jak również „krucyfiksy obejmujące” ukazują raczej nie stan, lecz akcję, ruch, przede wszystkim czynność obejmowania. W przypadku rzeźbiarskich krucyfiksów można zaobserwować zredukowanie sytuacji przedstawionej

20 V. Garibaldi, P. Mercurelli Salari, The Galleria Nazionale dell'Umbria. Guide, Milano 2007, s. 8. Tę część ekspozycji opracowała V. Garibaldi. Rzeźbę Chrystusa podpisano w muzeum: Cristo deposto.

21 H. Belting, op. cit., s. 118 n., 236 n., 256 n., il. 36, 37. Po raz pierwszy zapoznałem się ze szczególnie wartościową książką Hansa Beltinga dopiero w 2011 r., po napisaniu większości artykułu. Stąd też zawarte w artykule stwierdzenia różnią się jednak w pewien sposób od znaczących konstatacji Beltinga.

22 R. Salvi, Bernard z Clairvaux, święty, [w:] Nowy leksykon sztuki chrześcijańskiej, red. L. Castelfranchi, M. A. Crippa, Kielce 2013, s. 136. 
w dziełach malarskich oraz samej treści wizji. Czternastowieczne snycerskie krucyfiksy obejmujące to dzieła bardziej symboliczne, skupione w sobie, stworzone po to, by dokonywać ich percepcji jako całości. Specyfika rzeźby, jej funkcji oraz trójwymiarowy charakter - te cechy wywarły silny wpływ na skrótowe potraktowanie wizji i zarazem nie tak dosłowne jej przedstawienie, jak w dziełach malarskich. Osobę obejmowaną należy sobie wyobrazić. Ale wymienione Zdjęcie z krzyża z Luwru może wskazywać na możliwość wykonania trójwymiarowych przedstawień Bernarda i Ukrzyżowanego Chrystusa, przynajmniej w małej skali. Takie dzieła sztuki powstały w późniejszych epokach. W tym kontekście warto przypomnieć rozważania Rudolfa Berlinera o stosowaniu przez średniowiecznych artystów redakcji tematów ikonograficznych, dalekich od ścisłego trzymania się pierwowzo$\mathrm{ru}$ - przekazu pisanego oraz bliskich swobodzie artystycznej ${ }^{23}$. Na okładce zebranych esejów Berlinera umieszczono właśnie krucyfiks obejmujący z kościoła Neumünster w Würzburgu.

Cele omawianych przedstawień wyjaśnia, użyteczny nie tylko przy poznawaniu ikonoklazmu i jego zaprzeczenia, pochodzący z VIII wieku dodatek do listu Grzegorza Wielkiego (zm. 604), mówiący iż: „Twoja prośba wielce nas ucieszyła, ponieważ poszukujesz całym swoim sercem oraz całkowitym skupieniem Jego, którego obraz pragniesz mieć przed oczami, tak aby każdego dnia materialny widok czynił Go widzialnym. Tak więc, gdy patrzysz na obraz jesteś rozpalany w duszy miłością do Niego, na którego obraz pragniesz patrzeć. Nie czynimy nic złego pragnąc pokazać niewidzialne środkami widzialnymi”24.

23 R. Berliner, God is Love, w: idem, "The Freedom of Medieval Art” und andere Studien zum christlichen Bild, Berlin 2003, s. 90; idem, The Freedom of Medieval Art, w: idem, "The Freedom of Medieval Art”..., zwł. s. 60 n., 73 n.

24 Tłum. moje. „Your request pleased us greatly, because you seek with all your heart and all intentness Him, whose picture you wish to have before your eyes, so that every day, the corporal sight renders Him visible; thus, when you see the picture, you are inflamed in your soul with love for Him whose image you wish to see. We do no harm in wishing to show the invisible by means of the visible..., C. Hahn, Vision, [w:] A companion to medieval art. Romanesque and Gothic in Northern Europe, red. C. Rudolph, Malden, Mass 2006, s. 51 (Corpus Christianorum Series Latina 1110f.). 
Jan Szkot Eriugena (zm. 877) widział dzieła sztuki jako środki zobrazowania rzeczy transcendentalnych. Wpływ wywarł na niego Pseudo-Dionizy Areopagita oraz neoplatonizm ${ }^{25}$.

Przełożenie wizji na jakiekolwiek dzieło sztuki zawsze wiąże się ze zmianą przedstawienia wizualnego ze względu na niemożność pełnego oddania wizji zarówno w dziełach sztuki, jak i literatury. Przywoływany już Tomasz z Akwinu nawoływał do przekazywania innym owoców własnej kontemplacji - Contemplarii et contemplata aliis tradere ${ }^{26}$. Czyż stworzenie dzieła sztuki tak właściwego bogatej wizualnie kulturze średniowiecza nie jest najlepszym, najodpowiedniejszym przekazaniem wizji jak największej liczbie wiernych? Dzieło sztuki umożliwia przekazywanie idei, owoców kontemplacji wielkiej liczbie wiernych, w szczególności niepiśmiennym (illiterati), jako rodzaj Biblii ubogich (Biblia pauperum). „Krucyfiksy obejmujące" to nie tylko wyraz ówczesnej duchowości, wizji doświadczanych przez oculi cordis $^{27}$ (oczy serca) i w niedoskonały sposób przekazywanych ustnie, następnie zaś piórem, pędzlem i dłutem. To przede wszystkim dzieła sztuki. Storia obrazu lub rzeźby, przedstawienia wizualnego może daleko odbiegać od widzialnej realizacji lub spisanej wizji.

XIV wiek to stulecie rozkwitu mistyki, czasów Visio Dei. Żyjący wówczas ludzie pragnęli wizji, poznania Boga poprzez mistyczne doświadczenie, a nawet oglądania Go własnymi oczami ${ }^{28}$. To stanowiło największe pragnienia mistyka Henryka Suzona (zm. 1366).

Otto von Simson wskazuje na Bernarda z Clairvaux, ojca mistyki średniowiecznej, jako inspiratora tematu ikonograficznego Męża Boleści ${ }^{29}$. Bernard najchętniej widziałby krucyfiks jako jedyny element wyposażenia świątyni. Teologii miłości Bernarda odpowiada czternastowieczna mistyka Suzona określanego jako frater amandus - brat, który pragnął jedynie ko-

\footnotetext{
25 K. Bering, Romanik, Stuttgart 2004, s. 22.

26 J. A. Spież, Podstawowe cechy duchowości dominikańskiej, [w:] Duchowość zakonna: szkice, red. J. Kłoczowski, Kraków 1994, s. 57.

27 C. Hahn, op. cit., s. 55.

28 Ibidem, s. 59.

29 O. Simson, Bernhard von Clairvaux und der "dolce stil nuovo" der frühgotischen Plastik, w: idem, Von der Macht des Bildes im Mittelalter: Gesammelte Aufsätze zur Kunst des Mittelalters, Berlin 1993, s. 74, 76.
} 
chać Boga i być przez Niego kochanym. „Krucyfiksy obejmujące” z Würzburga, Heinrichs bei Suhl i Helmstedt datowane są różnie - na początek lub, nawet częściej, do około połowy XIV wieku. Mogły zatem powstać już po poważnych epidemiach, w trakcie działalności lub nawet po śmierci dominikanina Mistrza Eckharta (zm. 1328), w czasie działania na niedalekich terenach mistyków niemieckich, ich działalności apostolskiej, listownych kontaktów z licznymi klasztorami dominikańskimi prowincji Teutonii.

Koncepcje objęcia przewijały się również w XIV wieku u mistyków we wpływowych, bo wygłaszanych do ludu kazaniach, w szeroko rozpowszechnionych i przepisywanych tekstach. Mistycy opiekowali się i wizytowali klasztory na terenie dużej prowincji. Ich autorytet i aura cudowności oraz ustny przekaz mogły mieć duże znaczenie. Johannes Eckhart był przełożonym prowincji Teutonii, opiekował się 65 klasztorami dominikanek, a także beginażami. Był nowicjuszem, a następnie przeorem w stołecznym dla Turyngii Erfurcie, gdzie obecnie znajduje się „krucyfiks obejmujący” z pobliskiego, również turyńskiego Suhl. Następnie został prowincjałem Saksonii z siedzibą w Erfurcie, miejscu bliskim także Würzburgowi oraz odleglejszym, chociaż nieco pokrewnym ikonograficznie, przedstawieniom z Kastl i Forchheim. W Erfurcie głosił w kościele pasjonujące kazania. Następnie kontynuował działalność w Strasburgu. Przed lub w czasie powstania krucyfiksu z Suhl Eckhart był prowincjałem w Erfurcie. Działał zaś na pewno przed powstaniem krucyfiksów z Würzburga i Helmstedt ${ }^{30}$.

Tego wybitnego dominikańskiego teologa, oddanego pasji kaznodziejskiej, trafnie określano zarówno jako Lebmeister lub Lebemeister, czyli „mistrz życia”, jak i Lesemeister, czyli „mistrza słowa”, uczonego. Eckhart pragnął zbliżyć słuchających go wiernych do Boga poprzez własny mistycyzm, definiowany nawet jako w swej istocie mistycyzm Boski lub Boży - Gottesmystik ${ }^{31}$.

30 W. Szymona, Mistrz Eckhart, Kraków 2004, s. 13 n.

31 A. M. Haas, Szkoty późnośredniowiecznego mistycyzmu, [w:] Duchowość chrześcijańska, t. 2: Późne średniowiecze i reformacja, red. J. Raitt przy współpracy: B. McGinn, J. Meyendorff, Kraków 2011, s. 150, 153; W. Szymona, Wstęp, [w:] M. Eckhart, Kazania, przekł. i oprac. W. Szymona, Poznań 1986, s. 23. 
Dorobek Bernarda z Clairvaux i Mistrza Eckharta łączy obecna w ich dziełach mistycznych i teologicznych oszczędność obrazowych opisów dzieł sztuki, z pominięciem tekstów polemicznych autorytetu cysterskiego, w szczególności bernardyńskiej Apologii do opata Wilhelma z St. Thierry ${ }^{32}$.

Zawiłości filozoficznej mistyki Eckharta (mistrza świętej teologii, dwukrotnego profesora Sorbony) były mało zrozumiałe dla jemu współczesnych. Mogła jednak przemawiać wymowa pism, podjęta później przez zafascynowanego Eckhartem Henryka Suzo. Słowa Eckharta, homo religiosus, człowieka niesamowicie religijnego, nawet teolodzy papiescy rozumieli dosłownie, a nie w kontekście całokształtu skomplikowanej myśli. Osobowość, kazania oraz literackie dzieła Suzona i Eckharta mogły przemawiać do zleceniodawców i twórców dzieł sztuki.

W średniowiecznym nadreńskim mistycyzmie, w twórczości jego przedstawicieli: Eckharta, Suzona i Jana Taulera (zm. 1361), powtarza się motyw wielkiej, czułej miłości do Boga, pragnienie Jego bliskości, oglądania Go na własne oczy, compassio - cierpienia z Nim i obejmowania Go lub bycia przez Niego obejmowanym. Odpowiednikiem wizji Bernarda z Clairvaux jest Kazanie 86 Eckharta, które podejmuje motyw objęcia i bliskości ${ }^{33}$ : „Spójrz na ten cud: Jakiż niezwykły to stan! Być równocześnie na zewnątrz i wewnątrz: obejmować i być objętym, widzieć a równocześnie być tym, co się widzi, posiadać i być posiadanym. I to jest właśnie cel, przy którym duch trwa w spoczynku, zespolony z umiłowaną wiecznością"34.

32 U. Eco, Sztuka i piękno w Średniowieczu, Kraków 2006, s. 15 n., 140 n.; G. Henderson, Wczesne średniowiecze, Warszawa 2000, s. 94 n.

33 Prace Mistrza Eckharta przytaczam w ich opublikowanym tłumaczeniu na język polski, którego dokonał Wiesław Szymona. W przypisach podaję tłumaczenie na współczesny język niemiecki. Rezygnuję natomiast z (dostępnych w cytowanym, niemieckim wydaniu dzieł wszystkich Eckharta) wersji w średniowiecznym języku średniowysokoniemieckim (Mittelhochdeutsch).

34 M. Eckhart, Kazania, przekł. i oprac. W. Szymona, Poznań 1986, s. 463 (Kazanie 86). „Lausche »denn « nun auf das Wunder! Welch wunderbares Stehen draußen wie drinnen, begreifen und umgriffen, werden, schauen und $\gg$ zugleich « gehalten werden: das ist das Ziel, wo der Geist in Ruhe verharrt, der lieben Ewigkeit vereint": idem, Werke II: Predigten, Traktate. Text und Kommentar, wyd. i komentarz N. Largier, Deutscher Klassiker Verlag im Taschenbuch, t. 25, Frankfurt am Main 2008, s. 221 (Kazanie 86). 
Należy zwrócić uwagę na czasownik umgreifen. W omawianych tekstach Mistrza Eckharta nie ma bowiem słowa umarmen, które najbardziej kojarzy się z obejmowaniem i które zawarte jest w określeniu Umarmende Kruzifixe. Ale słowo umgreifen ma podobne znaczenie i może być w zbliżony sposób interpretowane, tak jak umarmen. Stanowi jego synonim i wyjaśnia się je także po prostu jako „obejmowanie rękoma”.

Wzajemną relację podkreśla również Kazanie $14^{35}$. Najwyższy cel stanowi mistyczne zjednoczenie z Bogiem - „oglądanie Boga bezpośrednio w Jego własnym Bycie"36, jest nim także objęcie, ogarnięcie przez Boga: „Przylgnij do Boga, a On ci przyda wszelkiej dobroci. Szukaj Go, a znajdziesz Jego samego, a wraz z Nim wszelkie dobro"37, jak również: „I tak mów: »Pragnę iść do Ciebie, bo chcę, by Twoje bogactwo wypełnito mój niedostatek, cała Twoja niezmierzoność zajęła moją pustkę, a Twoje nieskończone, niepojęte Bóstwo ogarnęło moje nikczemne, skażone człowieczeństwo «"38.

Kazania Eckharta cieszyły się wielką popularnością, dlatego uważam, że trafiały do ówczesnych wiernych, przekonywaty ich takie motywy jak: objęcie, zjednoczenie, bliskość Boga. Znacznie trudniej było zrozumieć abstrakcyjne rozważania Johannesa Eckharta o Bogu, którego da się pojąć tylko przez zaprzeczenia nie-Bóg, nie-Obraz (Nicht-Gott, Nicht-Bild) $)^{39}$. Tematy specyficznej bliskości Boga pojawiały się w ówczesnym mistycyzmie także w wizji Anieli z Foligno (zm. 1309), według której mistyczka, tercjarka franciszkańska znajdowała się z martwym Zbawicielem w Grobie.

\footnotetext{
35 Idem, Kazania..., s. 151 n. (Kazanie 14).

36 Ibidem, s. 463 (Kazanie 86). „Das Schauen Gottes in »seiner« reinen Natur”: idem, Werke II..., s. 221 (Kazanie 86).

37 Idem, Traktaty, przekł. i oprac. W. Szymona, Poznań 1987, s. 23 (Pouczenia duchowe, 2,5, Rozważ, co decyduje o dobroci twojej istoty i gtębi). „Hafte Gott an, so hängt er dir alles Gutsein an. Suche Gott, so findest du Gott und alles Gute »dazu «": idem, Werke II..., s. 345 (Traktat 2,5, Beachte was das Wesen und den Grund gut macht).

38 Idem, Traktaty..., s. 51 (Pouczenia duchowe 2,20, 0 częstym i pobożnym przyjmowaniu Ciata Pańskiego). „»Darum «, so sprich, » will ich zu dir gehen, auf daß dein Reichtum meine Armut erfülle und deine ganze Unermeßlichkeit erfülle meine Leere und deine grenzenlose, unfaßbare Gottheit erfülle meine allzu schnöde, verdorbene Menschheit «": idem, Werke II..., s. 399 (Traktat 2, 20, Von unseres Herrn Leib, daß man den oft empfangen soll und in welcher Weise und Andacht).

39 G. D’Onofrio, Historia teologii, t. 2: Epoka średniowieczna, Kraków 2005, s. 501 n., 505.
} 
Ona sama w aurze niezmiernej cudowności oraz radości, odczuwając niezwykle miłą woń została przytulona przez Odkupiciela, który również do niej przemówił ${ }^{40}$. Wcześniejszym przykładem podobnej, szczególnej bliskości i przepełnionej żalem, niemal lirycznej czułości jest malowidło ścienne Optakiwanie Chrystusa przez Matkę Boska i Jana Ewangelistę z cerkwi św. Pantelejmona w Nerezi o pięknym, urzekającym, pełnym głębi ujęciu tematu i zarazem wyrafinowanych formach datowane na 1164 rok.

W swoim liście 28 Henryk Suzon pisał o duszy, która często obejmuje Boga, a następnie Bóg wykonuje podobny gest w nagrodę w wiecznotrwałych zaświatach ${ }^{41}$. Celem jest zatracenie siebie, oddanie się w całości Bogu, mistyczne zjednoczenie. W Księdze Prawdy, na którą największy wpływ miała nauka Eckharta, zawarto słowa o mistycznym zjednoczeniu: „Trzymając się z dala od błędnych dróg, niech z całą mocą unicestwia samego siebie, niech umrze nieodwołalnie i w jedności z Chrystusem stanie się Jednym. W Nim niech wszystko czyni”².

Podobna do wizji Bernarda z Clairvaux jest późniejsza wizja Henryka Suzona: „Ujrzał tam unoszący się między niebem i ziemią obraz jakby człowieka na krzyżu, z wyrazem dobroci na twarzy [...] Naraz wydało mu się, że obraz niby rzeczywisty człowiek zniżył się, usiadł przy nim i zachęcił go do stawiania pytań, na które chciał usłyszeć odpowiedž‘‘3.

40 Antologia mistyków franciszkańskich, t. 2: wiek XIII-XIV, zebrał i red. S. Kafel, Warszawa 1986, s. 224.

41 H. Suzo, Księga Prawdy i inne pisma, przekł. i red. W. Szymona, Poznań 1989, s. 137 n. (list 28).

42 Ibidem, s. 27 (Rozdz. 4, O prawdziwym powrocie cztowieka oderwanego, dokonujacym sie przez Jednorodzonego Syna). "So daß er, ohne an etwas anderem zu schauen, mit aller Kraft sich in Gott verliere, sich in unwiderruflicher Weise seines selbst entäußere, auf solche Weise mit Christus eins werde, nach dessen Einsprechen aus ihm heraus allezeit wirke, alles entgegennehme und alle Dinge in solcher Einfachheit betrachte": H. Seuse, Deutsche mystische Schriften, przekł. i wyd. G. Hofmann, Düsseldorf 1966, s. 340 (Büchlein der Wabrheit, Kapitel 4, Von der wabren Einkehr, die ein gelassener Mensch durch den eingeborenen Sohn Gottes nehmen soll.).

43 H. Suzo, Ksiega Prawdy..., s. 30 (Rozdz. 5, O kilku wzniostych i pożytecznych zagadnieniach, które Prawda wyjaśnita uczniowi na przyktadzie cztowieka oderwanego). „Und da sah er zwischen Himmel und Erde ein Sinnbild schweben; das sah aus wie ein Mensch an einem Kreuze, voll gütigen Aussehens; [...] Da war ihm, als ob sich das Bild herabließe wie ein lebender Mensch: es setzte sich zu ihm und forderte ihn auf zu fragen, was 
W Erfurcie znajduje się witraż datowany na lata 1230-1235, który pokazuje wizję stygmatyzacji Franciszka z Asyżu. To cudowne zdarzenie miało na celu potwierdzić fizyczną tożsamość Franciszka z Ukrzyżowanym Chrystusem ${ }^{44}$. Dla ówczesnych ludzi najbardziej istotny i wpływowy był język obrazowy i literacki.

Jochen Hermann Vennebusch przytoczył dwa przykłady ze Starszej kroniki wielkich mistrzów, która została napisana w latach 1433-1440. Opisano w niej podobne, interesujące zdarzenia. W Wielki Piątek w kaplicy w Dzierzgoniu (Christburgu) jeden z braci pocałował rany krucyfiksu, który następnie próbował objąć zakonnika jedną ręką. W drugim przykładzie inny modlący się brat błagał Boga o znak i znów krucyfiks wykonał gest objęcia. Vennebusch porównuje do tych wizji omawiany krucyfiks z Würzburga. Podkreśla, że takie opisy i literatura mistyczna mogły być źródłem bardzo rzadkiego typu „krucyfiksów obejmujących”. Jednocześnie konstatuje, że krucyfiks z Würzburga nie należy do kręgu kultury zakonu krzyżackiego ${ }^{45}$. Ponadto kronika została napisana już po wykonaniu krucyfiksu z Würzburga. Legendarne cudowne wizje braci Zakonu Szpitala Najświętszej Panny Marii Domu Niemieckiego w Jerozolimie wykazują czytelne podobieństwa do wizji Bernarda z Clairvaux, przekazanej przez Konrada z Eberbach.

Podobnie Alois Maria Haas wskazał, analizując dorobek Henryka Suzona, że mistycyzm pasyjny uobecniał się nie tylko w mistycznych dziełach literackich, lecz również w ówczesnych dziełach sztuki, szczególnie tych ukazujących Męża Boleści ${ }^{46}$. Na Henryka Suzo, znanego jako frater amandus, bardzo silny wplyw wywarł Mistrz Eckhart. Suzon tworzył przede wszystkim po swoim mistrzu jako jeden z trzech najważniejszych przedstawicieli mistycyzmu nadreńskiego.

Współczesne krucyfiksy otrzymują najróżniejsze kształty. Przykłady takich rzeźbiarskich Ukrzyżowań z Warszawy i Torunia wyróżniają się ce-

er wissen wolle: es werde ihm Antwort zuteil": H. Seuse, Deutsche mystische Schriften..., s. 343 (Büchlein der Wabrbeit, Kapitel 5, Von den hohen und nützlichen Fragen, die ibm die Wabrheit vom Bilde eines gelassenem Menschen beantwortete).

44 A. Vauchez, Duchowość średniowiecza, Gdańsk 2004, il. 7, s. 115.

45 J. H. Vennebusch, Zentrale Facetten der Spiritualität des Deutschen Ordens im Spiegel der "Älteren Hochmeisterchronik”, „Ordines Militares Colloquia Torunensia Historica. Yearbook for the Study of the Military Orders", XVIII, 2013, s. 260 n., 264.

46 A. M. Haas, op. cit., s. 158. 
chami, które przywołują „krucyfiksy obejmujące”. Ich ramiona ułożone są jako wyraźnie oderwane od poziomej belki krzyża w geście przypominającym szerokie objęcie. W ich kontekście warto zacytować siedemnastowieczną grafikę z Norymbergii, przedstawiającą Bernarda z Clairvaux ${ }^{47}$. Chrystus nie tylko obejmuje, lecz raczej zdecydowanie oddziela ramiona od belki krzyża. Nie umieszcza ich na piersi, lecz znajdują się one poruszone w przestrzeni. Można nadmienić, że typ Amplexus przedstawiający Jezusa i Bernarda z Clairvaux został rozpowszechniony przez ryciny ${ }^{48}$.

Odbiorcy dzieł sztuki nie muszą pamiętać, kim był i kiedy żył autor wizji. Przyjmują to, co jest obecne w sztuce ich czasów. To, co w ich epoce jest poddawane interpretacji na nowo, po raz kolejny rozważane lub tylko podejmowane. To tylko może powstać w danej epoce, co jest możliwe w danym czasie, miejscu i uwarunkowaniach.

Obecnie rozwinięte zostaną rozważania dotyczące relacji pomiędzy słowem a obrazem w dojrzałym i późnym średniowieczu. W szczególności na przykładzie paralel i odniesień do alegorii Dobrej i Złej Modlitwy w dziełach Mistrza Eckharta i Jana Taulera. W trakcie analizy warto mieć przed oczami dla przykładu malowidła ścienne na sklepieniach kościołów w Elmelunde i Fanefjørd na duńskiej wyspie Møn, datowane na połowę XV wieku ${ }^{49}$. Na freskach Zła Modlitwa pod Ukrzyżowanym i pod Mężem Boleści kieruje się do bogactw, dóbr świata doczesnego. Odwraca się od Zbawiciela. Dobra Modlitwa jest zanoszona bezpośrednio do ran cierpiącego Odkupiciela. Także mistycy w swoich kazaniach, listach i traktatach kładli szczególny nacisk na kontemplację ran, cierpienia i ofiary Chrystusa.

Niewłaściwe odnoszenie się do Boga zostało wskazane przez Mistrza Eckharta w Kazaniu 16b na przykładzie wiernego, który kocha Boga, ale tylko dlatego, że kocha rzeczy doczesne ${ }^{50}$. Jak powinna wyglądać modlitwa? „Człowiek powinien następnie prosić, żeby Bóg to mu dał i nauczył go

47 Norymberga, Germanisches Nationalmuseum, Graphische Sammlung, Inv.-Nr. HB 5369, rzeźby Chrystusa na krzyżu w Warszawie w kościele św. Jacka i w Toruniu w kościele Matki Bożej Królowej Polski.

48 J. Seibert, Leksykon sztuki chrześcijańskiej: tematy, postacie, symbole, Kielce 2007, s. 48 .

49 G. Jurkowlaniec, op. cit., il. 91-92.
50 M. Eckhart, Kazania..., s. 161 (Kazanie 16b). 
o to prosić, co Jemu się w naszych modlitwach i pobożnych ćwiczeniach najbardziej podoba i co człowiekowi najwięcej przynosi pożytku. Wtedy możemy się oddać każdej modlitwie, niezależnie od jej konkretnej formy; mogą to być rozważania o Bóstwie, Trójcy Świętej, męce czy ranach naszego Pana. [...] Proś Ojca niebieskiego, żeby przez swego jednorodzonego Syna sam On w najmilszy sposób stał się przedmiotem twojej modlitwy" 51 .

Czy wierny może poszukiwać czegokolwiek innego poza Bogiem, czy coś innego może być przedmiotem modlitwy wiernych? W swoim Kazaniu 26 Mistrz Eckhart stwierdził, że kto poszukuje Boga i jednocześnie czegoś poza Nim, nie odnajdzie Boga ${ }^{52}$. Podczas gdy w Kazaniu 25 powiedział, że Bóg sam w swojej istocie jest największym darem ${ }^{53}$. W traktatach zaś nakazywał: „Człowiek ma przede wszystkim zawsze zwracać się ku darom Bożym i ciągle w tym kierunku ponawiać próby” ${ }^{24} \mathrm{i}$ „Wierzcie mi, ani Bóg, ani cały świat nie pomogą znaleźć prawdziwej pociechy człowiekowi, który jej szuka u stworzeń. Kto by natomiast w stworzeniach kochał jedynie Boga, te zaś tylko w Nim, ten by wszędzie znajdywał prawdziwą, dobrą i jednaką pociechę"55.

W kazaniach Jan Tauler podobnie tłumaczył: „W ten sposób powinniśmy wznosić się ponad nas samych i ponad wszystko, co nie jest Bogiem,

51 J. Tauler, Kazania, przekł. i oprac. W. Szymona, Poznań 1985, s. 143 (Kazanie 17). „Nun soll der Mensch darum bitten, dass Gott ihm gebe und ihn um das bitten lehre, was ihm - Gott - am allermeisten in des Menschen Gebet und seinen Übungen der Andacht gefällt und dem Menschen am nützlichsten ist. Welche Art (des Gebetes) sich ihm dann darbietet, die soll er für sich anwenden, sie betreffe die Gottheit, die heilige Dreifaltigkeit, das Leiden oder die Wunden unseres Herrn [...] Bitte den himmlischen Vater, dass er durch seinen eingeborenen Sohn sich selber dir in der wohlgefälligsten Weise zum Gegenstand (deines Gebetes) mache”. J. Tauler, Predigten, vollständige Ausgabe, przekł. i wyd. G. Hoffmann, Freiburg im Breisgau 1961, s. 116 (Kazanie 17).

52 M. Eckhart, Kazania..., s. 210 (Kazanie 26).

53 Ibidem, s. 207 (Kazanie 25).

54 Idem, Traktaty..., s. 57 (Pouczenia duchowe). „Vor allen Dingen soll sich der Mensch allzeit auf die Gaben Gottes gerichtet halten und immer wieder von neuem": idem, Werke II..., s. 409 (Traktat 2, 21, Vom Eifer).

55 Idem, Traktaty..., s. 87 (Ksiega Boskich pocieszeń I, 1). „Wahrlich, es ist Gott und aller dieser Welt wirklich unmöglich, daß der Mensch wahren Trost finde, der Trost sucht bei den Kreaturen. Wer aber Gott allein in der Kreatur liebte und die Kreatur allein in Gott, der fände wahren, rechten und gleichen Trost allerorten”: idem, Werke II..., s. 243 (Traktat 1, 1, Das Buch der göttlichen Tröstung). 
niczego oprócz Niego nie pragnąc, niczego nie kochając; ten czas zawsze do nas należy. [...] Samo to pragnienie jest jednak niewystarczające, Boga musimy bowiem szukać i dążyć do Niego ze względu na Niego samego"56.

Warto zapoznać się z wizją Chrystusa ukazującego Swoje pięć ran, którą zawarto w kronice krzyżackiej z pierwszej połowy XIV wieku. W wizji tej narzuca się przeciwstawienie sobie doczesnego piękna, splendoru, wspaniałych szat i z drugiej strony najbardziej podstawowego celu, jakim są rany Zbawiciela Świata: „I kiedy tak przez jakiś czas pozostawał w niepewności co do złożenia ślubów zakonnych, diabeł, nieprzyjaciel rodzaju ludzkiego, który zna tysiące sposobów szkodzenia, chciał go odwieść od tego świętego zamiaru i ukazał mu się we śnie w królewskiej szacie w otoczeniu licznego rycerstwa i rzekł mu: »Henryku, będziesz miał dla siebie wielkie miasto i wielki zamek, będziesz dzielnym rycerzem, ale jeśli będziesz mi służył, dam ci jeszcze więcej«. I gdy przemyśliwał w sobie, jakimi zasługami miałby się odwdzięczyć tak hojnemu panu, ukazał się Jezus Chrystus z pięcioma ranami i powiedział: »Henryku, ja jestem hojniejszy od niego «; następnie dotknął swojej rany w boku i rzekł: »Takie oto miasto dam tobie, jeśli mi będziesz służył, które jest o wiele lepsze od tego, jakie ci daje ów król fałszywy «"

56 J. Tauler, Kazania..., s. 112 (Kazanie 12). „Und so sollen wir uns erheben über uns selber und über alles, was nicht Gott ist, indem wir nur ihn wollen, nur ihn lieben und nichts anderes; diese Zeit ist stets unser. [...] Aber dieses Verlangen genügt nicht; Wir müssen Gott erstreben und suchen um seiner selbst willen”: idem, Predigten..., s. $83 \mathrm{n}$.

57 Piotr z Dusburga, Kronika ziemi pruskiej, przekł. S. Wyszomirski, Toruń 2005, s. 200 (III, 284, O bracie Henryku z Cunce). „Et sic dum quasi dubius in voto complendo per tempus aliquod existeret, diabolus humani generis inimicus, qui mille modos nocendi habet, volens ipsum a sancto suo proposito retardare apparuit ei in somnis in habitu regio et multa stipatus militia ait: »Henrice, talem civitatem et tale castrum habeas tu et sis miles strenuus et servias mihi et amplius tibi dabo «. Cum autem ipse cogitaret intra se, quod merito deberet servire tali domino largo, apparuit Iesus Christus cum quinque vulneribus et ait: »Henrice, ego sum largior illo«; et tacto vulnere lateris dixit: $\gg$ Hanc civitatem dabo tibi, si servieris mihi, quae multo melior est illa, quam tibi seductor ille rex promisit«": Petrus de Dusburgk, Chronica terrae Prussiae, wyd. i komentarz J. Wenta, S. Wyszomirski, Monumenta Poloniae Historica, nova series, t. 13, Cracoviae 2007, s. 229 n. (Rozdz. 284, De fratre Henrico de Cunce). W tej kronice również pojawia się cudowny motyw próby objęcia rycerza krzyżackiego przez snycerską postać Ukrzyżo- 
Czy rozważone wizje, znaczenia, treści tekstów to jedyne wyjaśnienie fenomenu „krucyfiksów obejmujących”? Z pewnością nie. W starszej literaturze przywołano legendarne wyjaśnienie gestu objęcia, jakim cechuje się krucyfiks z Würzburga, jako gestu obrony przed złodziejem, który usiłował ukraść cenną koronę cierniową. Gest miał zostać upamiętniony w rzeźbie jako wiecznotrwała przestroga. Egid Beitz zaznaczył, że cechy legendy wskazują, iż powstała ona później aniżeli w czasach średniowiecznych ${ }^{58}$. Należy przypuszczać, że większe znaczenie miało mistyczne Amplexus Christi. Jednak nie tylko to najbardziej znane, wiązane z Bernardem z Clairvaux - Amplexus Bernardi. Istotne znaczenie miały zapewne również motywy objęcia, bliskości, mistycznej miłości obecne w tekstach innych mistyków, przede wszystkim tych omówionych powyżej. Ich działalność była zresztą wpływowa na terytorium, z którego prawdopodobnie pochodzą krucyfiksy. Dwa z Ukrzyżowań znajdują się w bliskiej geograficznie odległości. Wpływ wcześniejszych rzeźbiarskich grup Zdjęć z krzyża oraz malarskich przedstawień typu Amplexus jest wyraźny. Zdjęcia z krzyża i takie malarskie przedstawienia były znacznie popularniejsze aniżeli snycerskie, czternastowieczne krucyfiksy obejmujące.

Przywołane kazania i traktaty Mistrza Eckharta oraz innych mistyków nie stanowią raczej źródła mistycznych „krucyfiksów obejmujących”, lecz ich istotny kontekst. Rozważane rzeźby i przekazy pisemne to przykłady połączeń, relacji pomiędzy wizualną, ustną i pisemną kulturą, datującą się głównie na pierwszą połowę XIV wieku.

Należy mieć na uwadze, że zaledwie kilka snycerskich gotyckich „krucyfiksów obejmujących", krótki opis wizji Bernarda z Clairvaux i, co prawda, imponująca literacka spuścizna innych mistyków oddają jedynie cząstkę ówczesnej sztuki, świata idei, tradycji ustnej, dyskusji, wyjaśnień. To wszystko, co wiadomo, do czego udało się dotrzeć można określić jako pars pro toto - uchwyconą część, zamiast dawniej istniejącej całości. I przedstawiony artykuł to próba wyjaśnienia ikonograficznego, średniowiecznego fenomenu, a nie ostateczna odpowiedź.

wanego Chrystusa: Piotr z Dusburga, Kronika..., s. 86 (III, 64, O pobożnym życiu braci $w$ Dzierzgoniu).

58 E. Beitz, Die Quellen der Kruzifixe aus Neumünster zu Würzburg und aus Heinrichs, „Cicerone”, XVI, 1924, s. 722. 


\section{Przemystaw Waszak}

\section{Gothic "embracing crucifixes"}

and their wood carved examples from

Würzburg, Suhl-Heinrichs and Helmstedt - summary

Gothic "embracing crucifixes" carved in wood, although known from only a few examples, constitute a real iconographic phenomenon of the $14^{\text {th }}$ century worth closer scrutiny and renewed appraisal. These sizeable objects be it of natural, or larger-than-life dimensions - are characterized by a particular disposition of hands; moreover, they also differ from later examples, which are less symbolic, more free in composition, and better corresponding to painterly and graphic images of the subject. The nomenclature of "embracing crucifixes" is reviewed in the paper, and the question of their visual classification as being part of the Man of Sorrows type revisited.

The interpretation of these objects must inevitably refer to the essential vision of St. Bernard of Clairvaux - the Amplexus Christi. The motif of embrace is also present in writings of other medieval mystics, theologians and chroniclers. The theme of tender and devoted love towards God, and of desire for cosuffering is especially legible with Henry Suso. However, of highest importance is the consideration of fragments of sermons and treatises by Johannes Eckhart von Hochheim, "the master of life and word". The motif of embrace, closeness and submersion of human soul in God is constantly present in his writings.

These sources form the background necessary to undertake any attempt at interpretation of works of art in question, even if the themes of spiritual embrace and closeness are more widespread in literature and art of the period, particularly in the first half of the $14^{\text {th }}$ century. In visual sphere, they include the related subject of Allegory of Good and Bad Prayer, but significant affinities with the "embracing crucifixes", whether visible in formal gesture, or in embodiment of theological idea, also exist in some sculptural or painterly representations of Christ in Tomb, Crucifixion, Lamentation, Virgin of Mercy, and especially Descent from the Cross. 


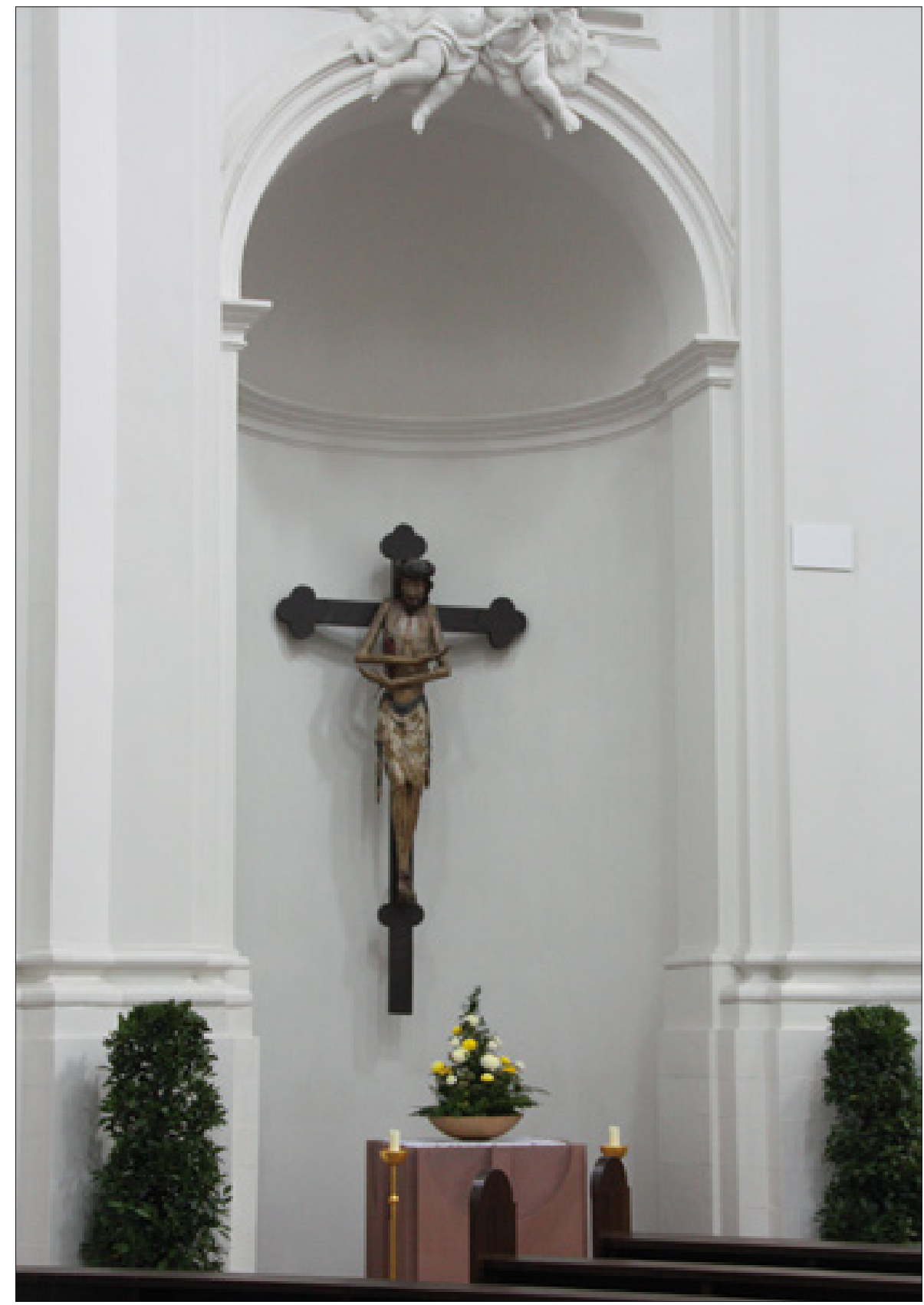

Ilwstracja 1

Würzburg, Neumünsterkirche, „krucyfiks obejmujący”, połowa XIV w. - widok ogólny w przestrzeni kościoła. Fot. P. Waszak 


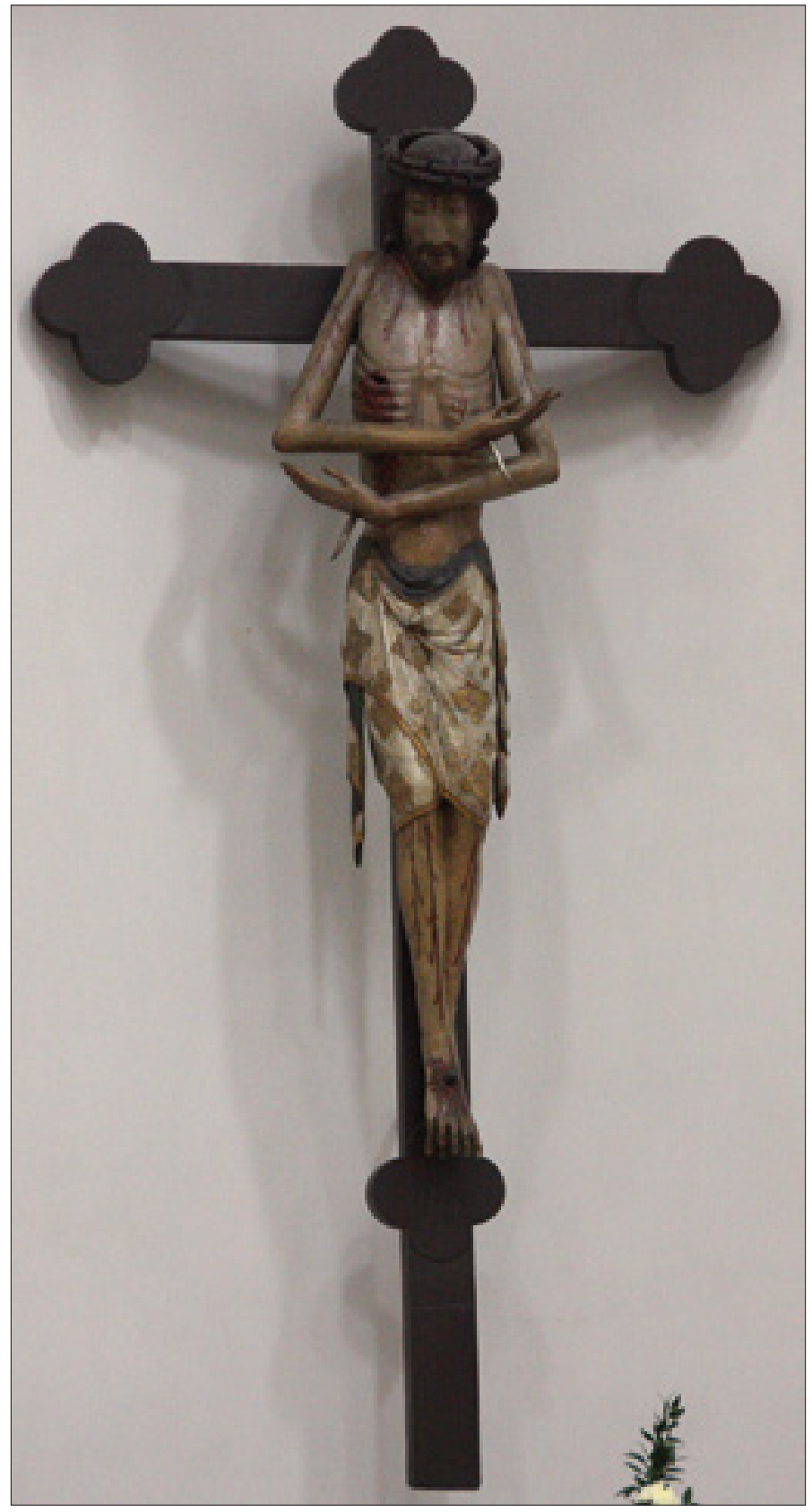

Ilustracja 2

Würzburg, Neumünsterkirche, „krucyfiks obejmujący”, połowa XIV w. - całość krucyfiksu. Fot. P. Waszak 


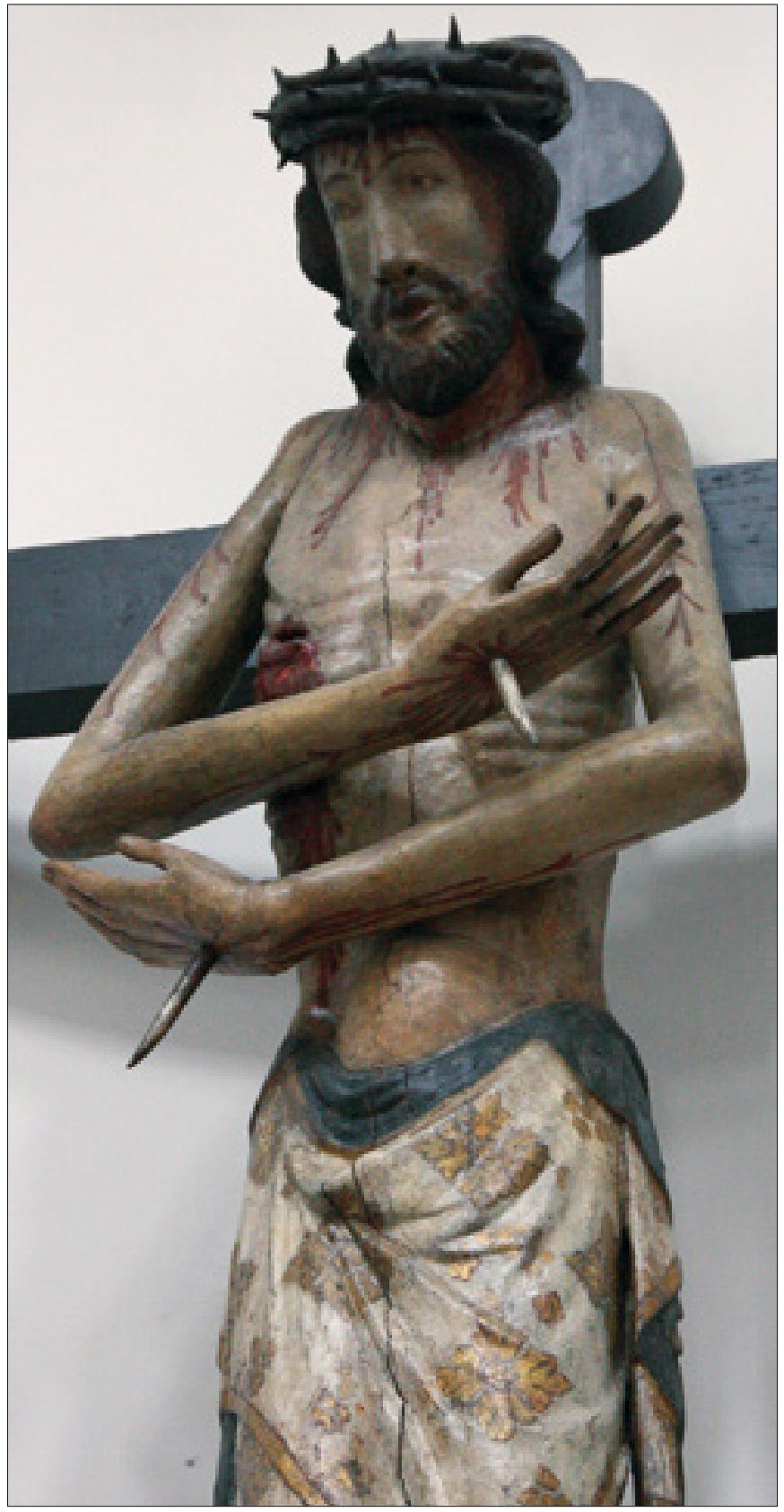

Ilustracja 3

Würzburg, Neumünsterkirche, „krucyfiks obejmujący”, połowa XIV w. - górna część rzeźby. Fot. P. Waszak 


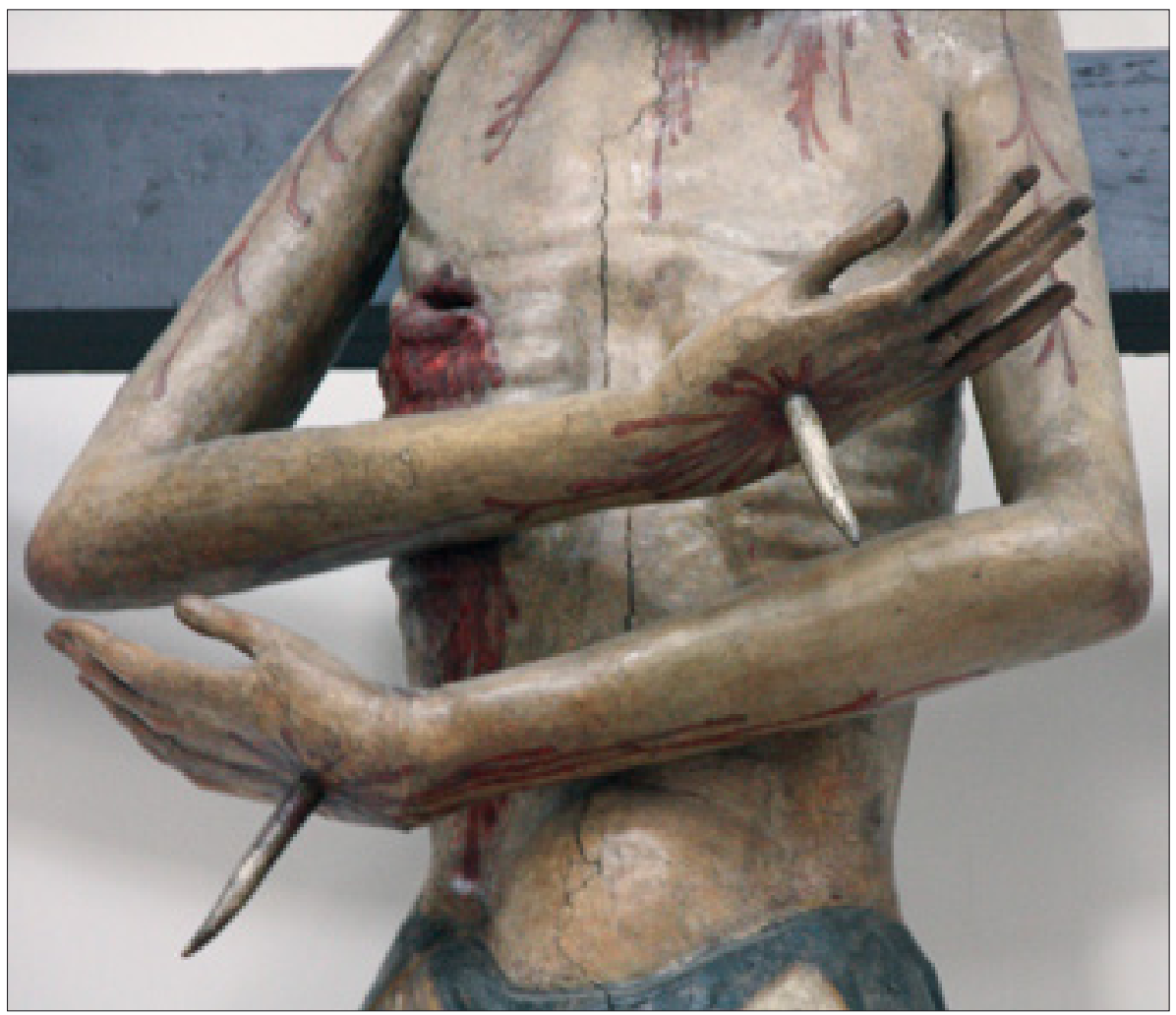

Ilustracja 4

Würzburg, Neumünsterkirche, „krucyfiks obejmujący”, połowa XIV w. - „obejmujące” ramiona. Fot. P. Waszak 


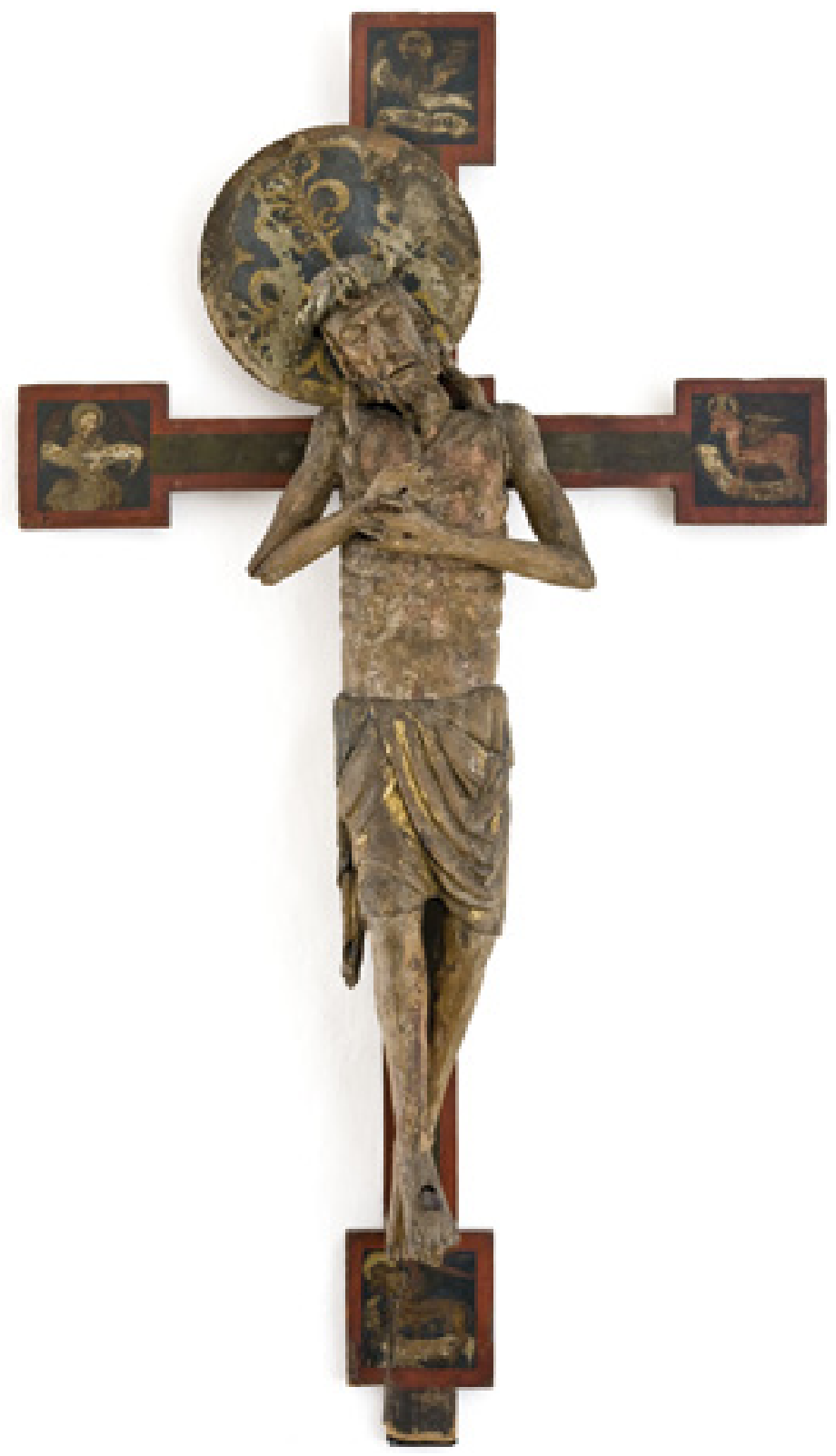

Ilustracja 5

Suhl-Heinrichs, „krucyfiks obejmujący”, połowa XIV w. ze zmianami datującymi się na XV i XVI w. - widok ogólny. Obecnie w zbiorach Angermuseum Erfurt, depozyt parafii ewangelickiej Suhl-Heinrichs. Fot. D. Urban 


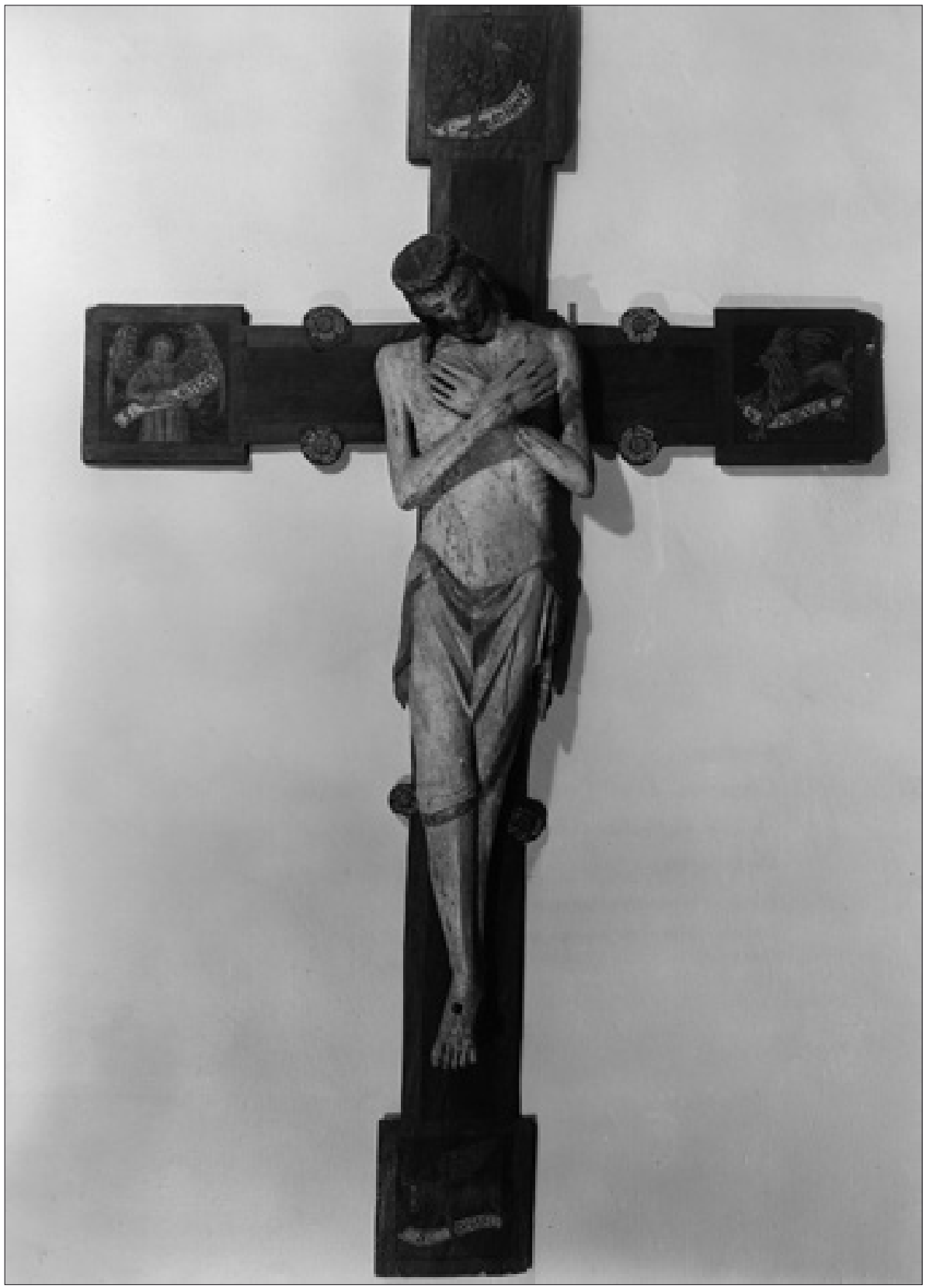

Ilustracja 6

Helmstedt, kościół St. Marienberg, „krucyfiks obejmujący” z kaplicy szpitala św. Jerzego na przedmieściu Neumark, połowa XIV w., krzyż z końca XV w. - widok ogólny. Fot. ze zbiorów Niedersächsisches Landesamt für Denkmalpflege w Hanowerze 


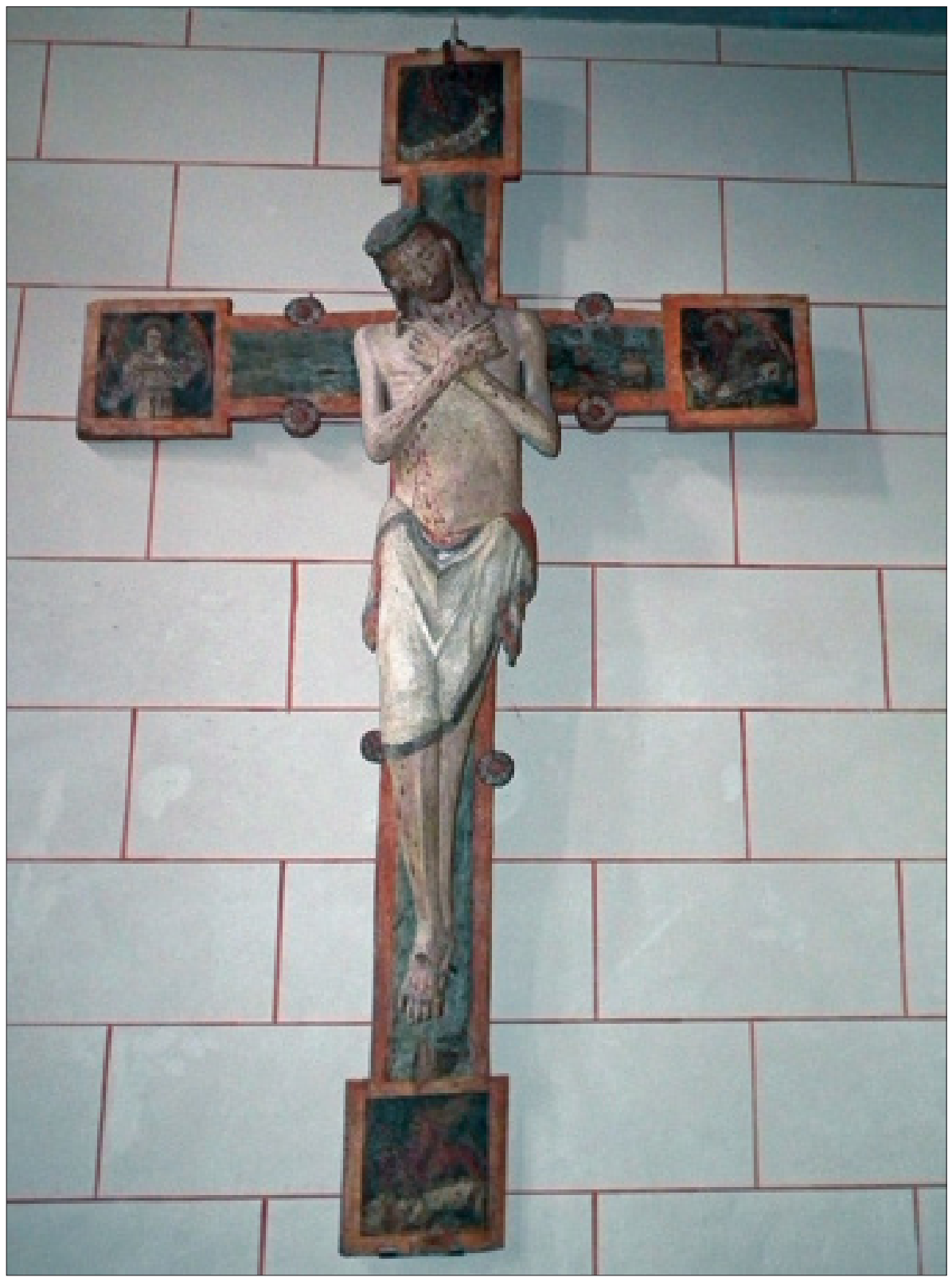

Ilustracja 7

Helmstedt, kościół St. Marienberg, „krucyfiks obejmujący” z kaplicy szpitala św. Jerzego na przedmieściu Neumark, połowa XIV w., krzyż z końca XV w. - widok ogólny. Fot. G. Klaffehn 


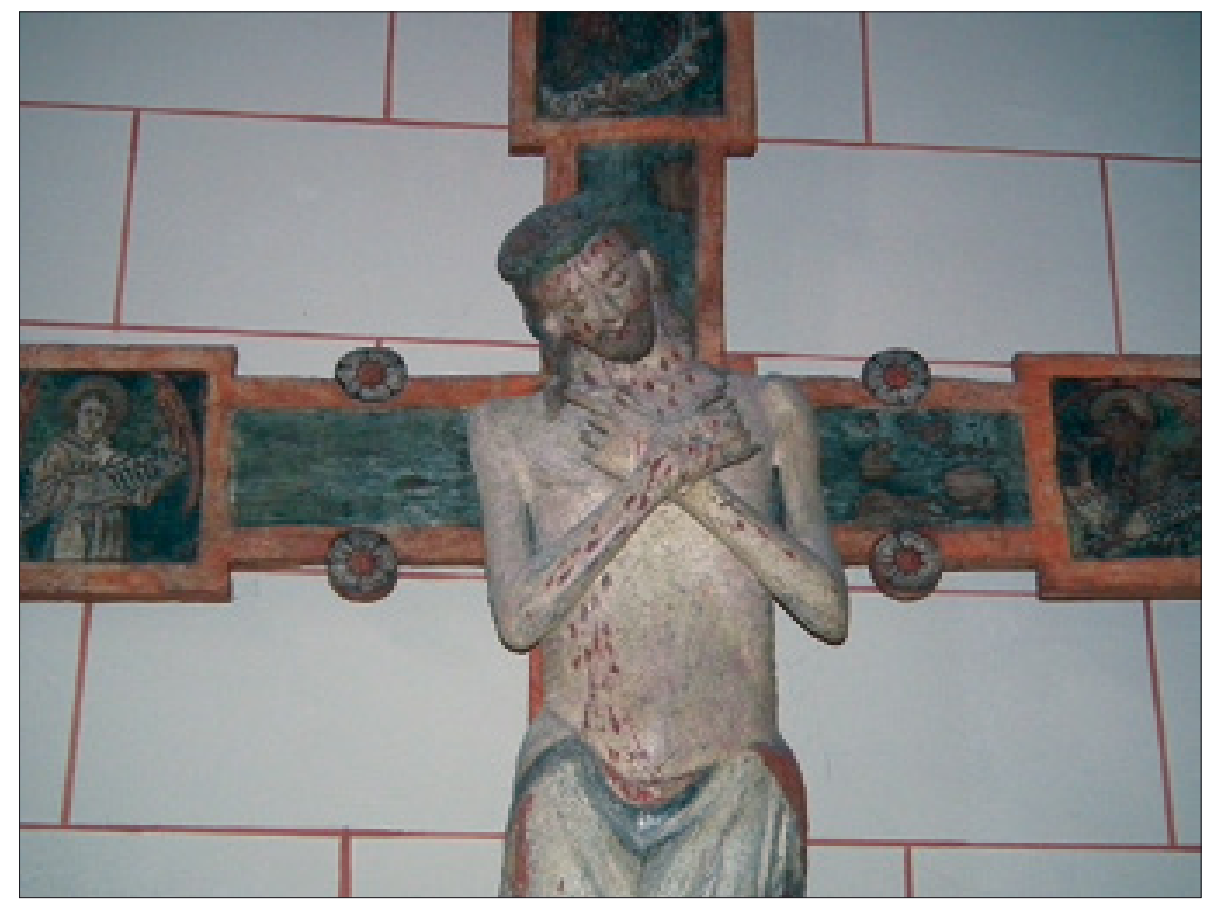

Ilustracja 8

Helmstedt, kościół St. Marienberg, „krucyfiks obejmujący” z kaplicy szpitala św. Jerzego na przedmieściu Neumark, połowa XIV w., krzyż z końca XV w. - górna część rzeźby. Fot. G. Klaffehn 


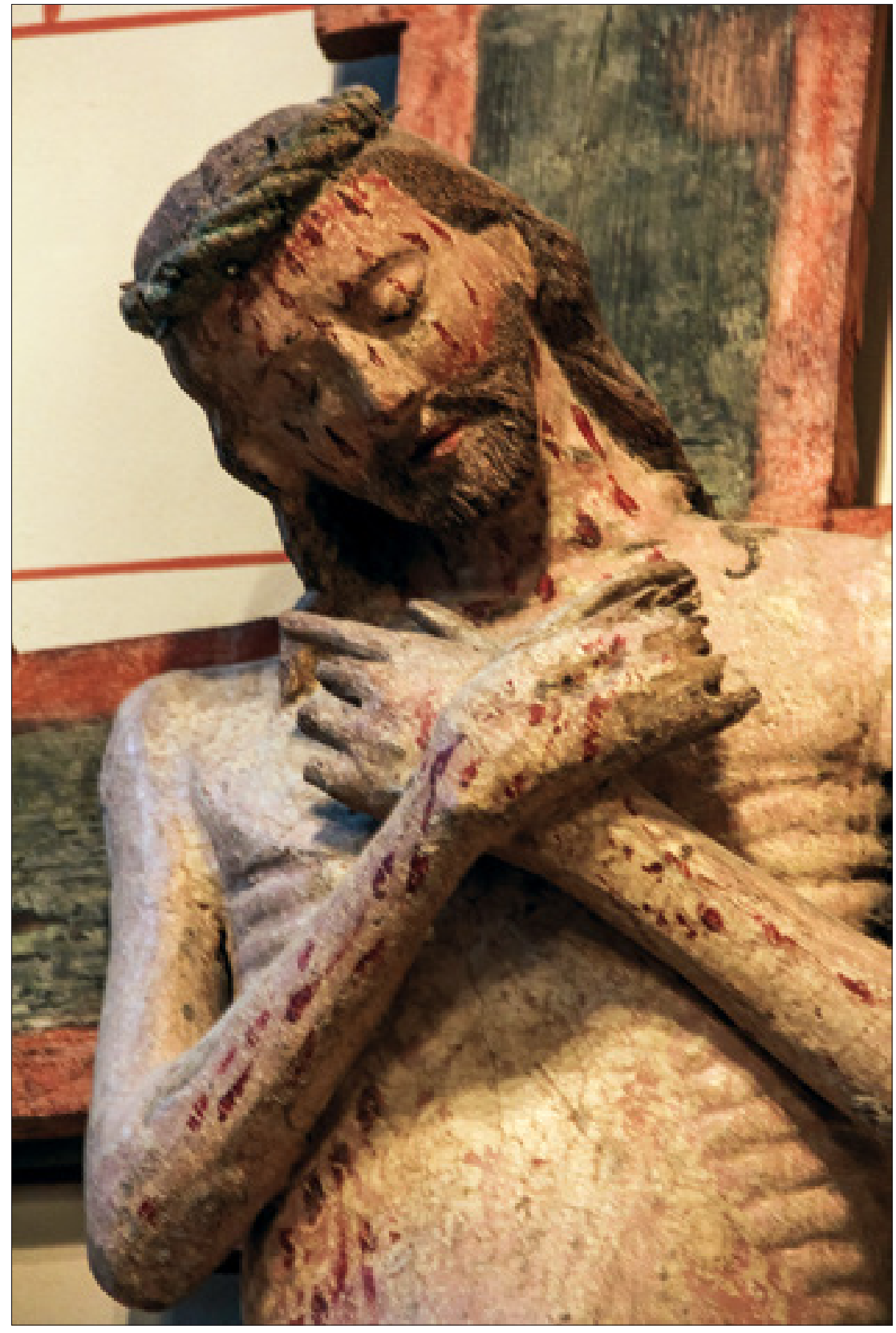

Ilustracja 9

Helmstedt, kościół St. Marienberg, „krucyfiks obejmujący” z kaplicy szpitala św. Jerzego na przedmieściu Neumark, połowa XIV w., krzyż z końca XV w. - głowa i ramiona. Fot. G. Klaffehn 


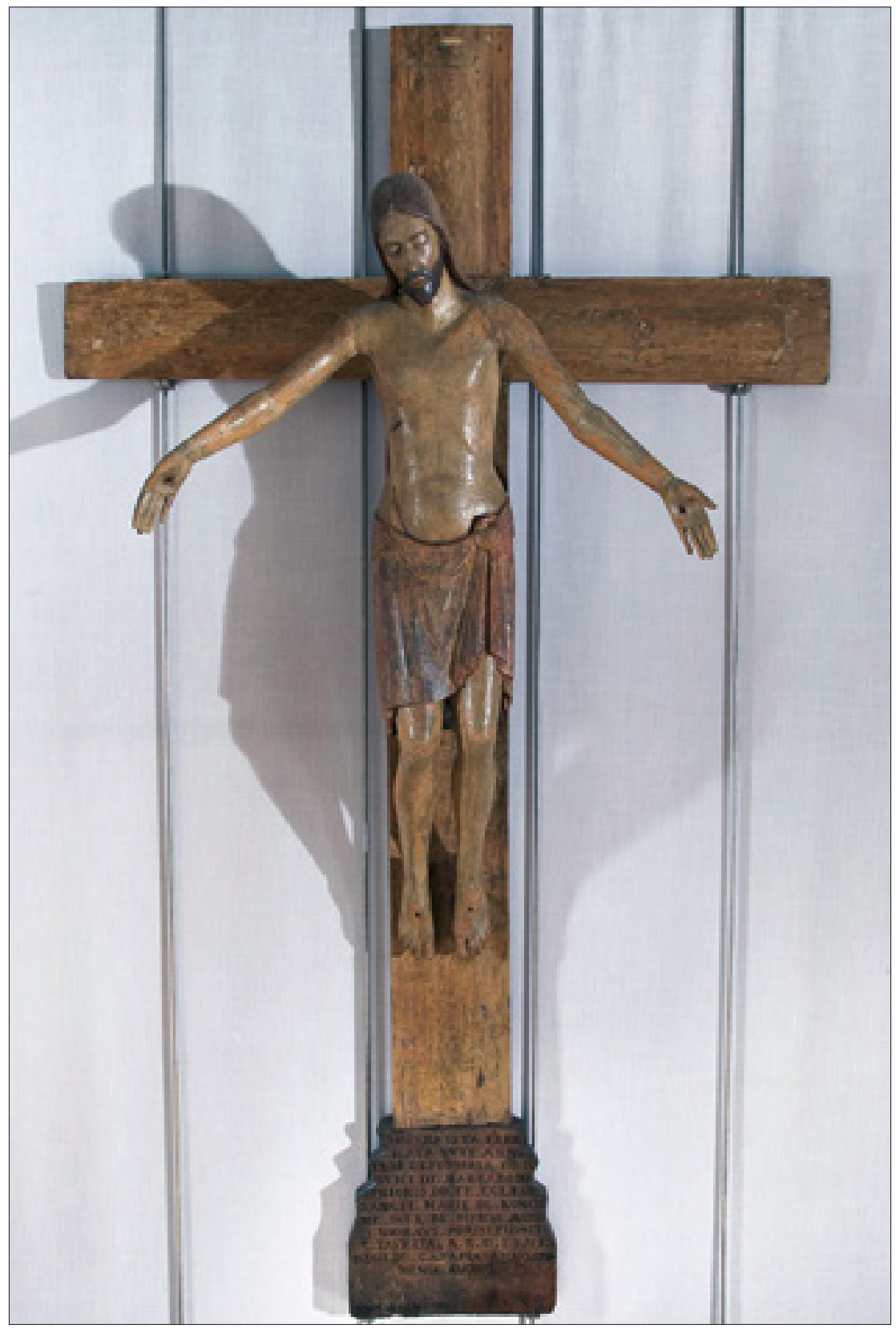

Ilustracja 10

Roncione, kościół Santa Maria, Cristo deposto, przed 1236 r. - widok ogólny. Eksponowany w Galleria Nazionale dell'Umbria w Perugii. Fot. ze zbiorów Galleria Nazionale dell'Umbria 


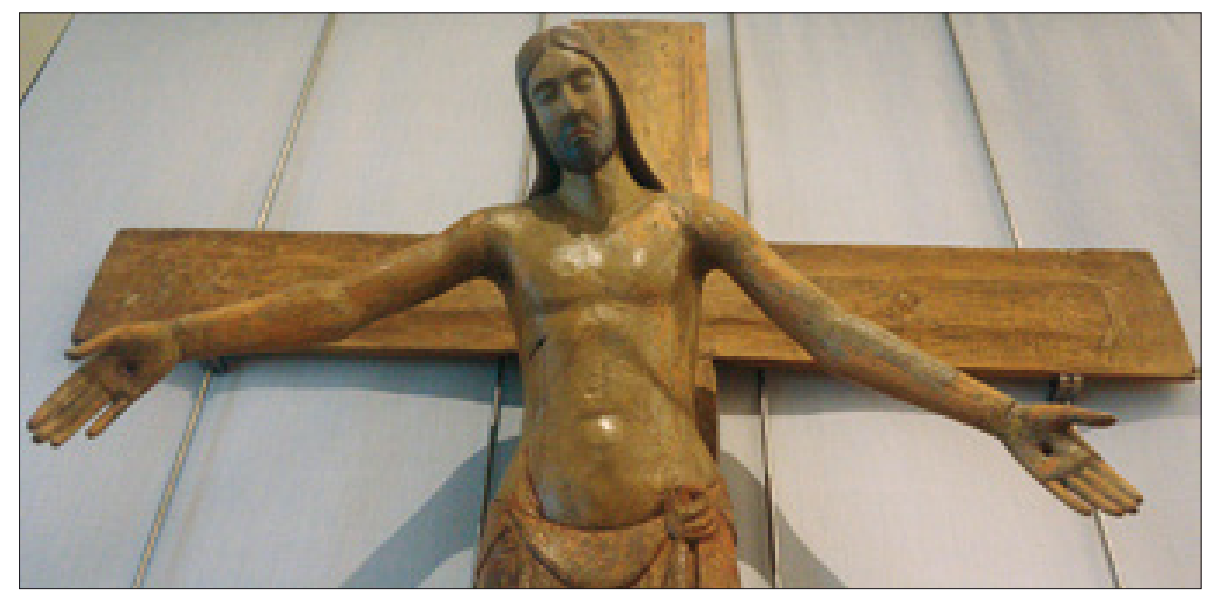

Ilustracja 11

Roncione, kościół Santa Maria, Cristo deposto, przed 1236 r. - górna część rzeźby. Eksponowany w Galleria Nazionale dell'Umbria w Perugii. Fot. P. Waszak 


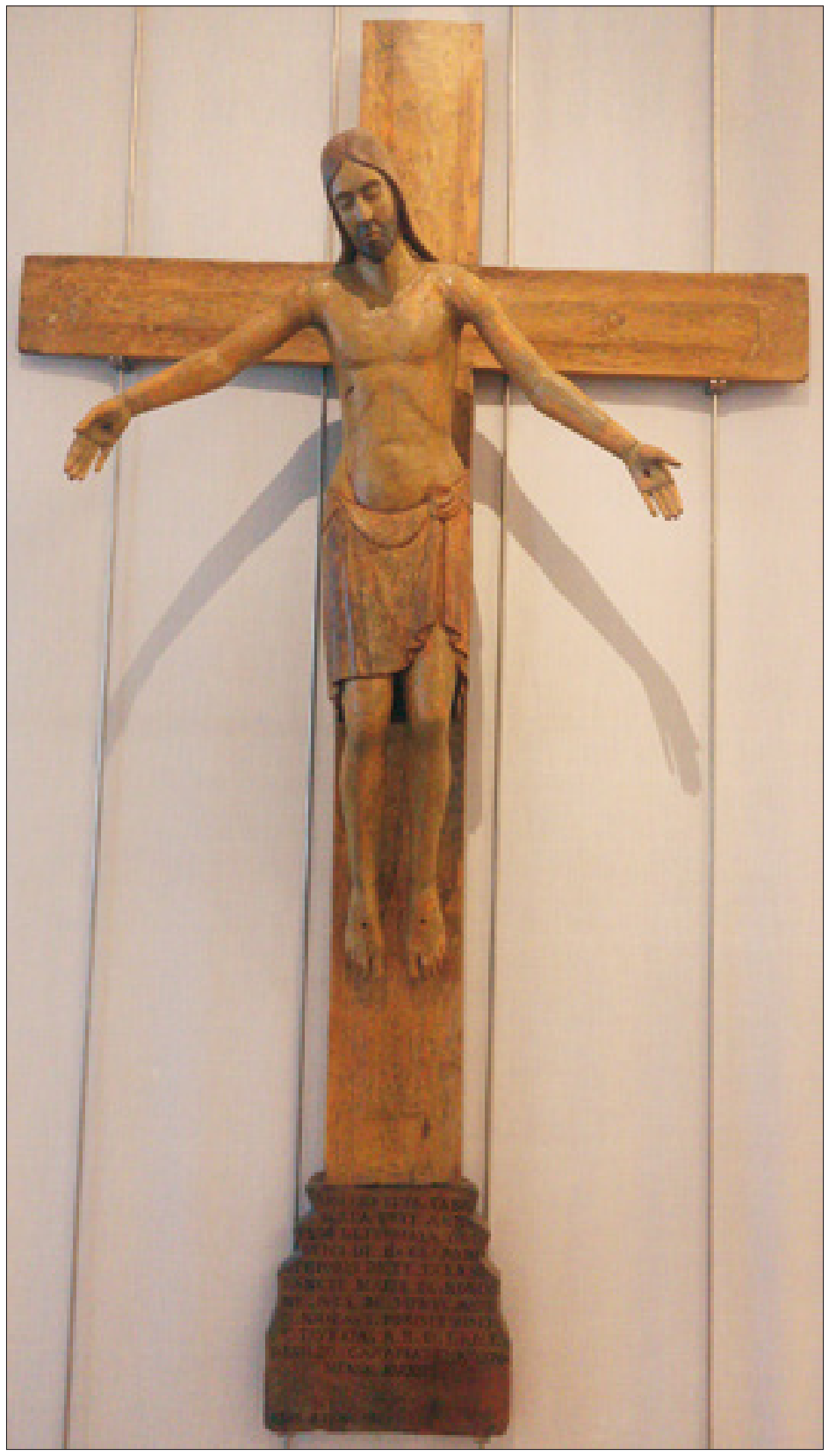

Ilustracja 12

Roncione, kościół Santa Maria, Cristo deposto, przed 1236 r. - widok ogólny. Eksponowany w Galleria Nazionale dell'Umbria w Perugii. Fot. P. Waszak 